
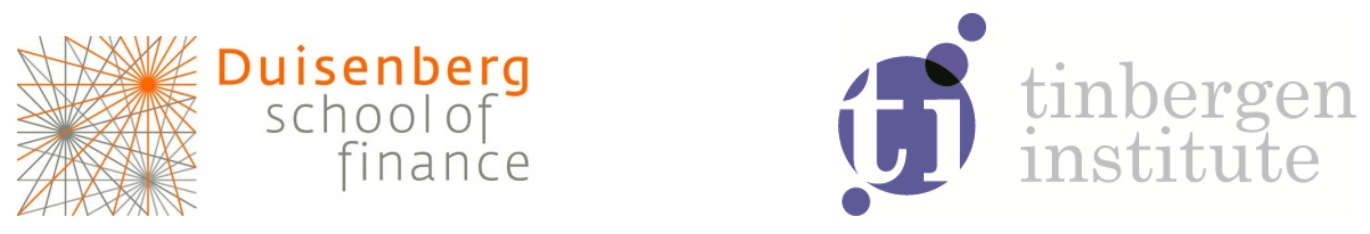

Duisenberg school of finance - Tinbergen Institute Discussion Paper

TI 13-087 / VI / DSF 57

Sukuk Defaults:

On Distress Resolution in Islamic

Finance

Sweder van Wijnbergen

Sajjad Zaheer

Amsterdam School of Economics, University of Amsterdam, and Tinbergen Institute. 
Tinbergen Institute is the graduate school and research institute in economics of Erasmus University Rotterdam, the University of Amsterdam and VU University Amsterdam.

More TI discussion papers can be downloaded at http://www.tinbergen.nl

Tinbergen Institute has two locations:

Tinbergen Institute Amsterdam

Gustav Mahlerplein 117

1082 MS Amsterdam

The Netherlands

Tel.: +31(0)205251600

Tinbergen Institute Rotterdam

Burg. Oudlaan 50

3062 PA Rotterdam

The Netherlands

Tel.: +31(0)10 4088900

Fax: $+31(0) 104089031$

Duisenberg school of finance is a collaboration of the Dutch financial sector and universities, with the ambition to support innovative research and offer top quality academic education in core areas of finance.

DSF research papers can be downloaded at: http://www.dsf.nl/

Duisenberg school of finance

Gustav Mahlerplein 117

1082 MS Amsterdam

The Netherlands

Tel.: +31(0)20 5258579 


\title{
Sukuk Defaults: on Distress Resolution in Islamic Finance
}

\author{
Sajjad Zaheer * \\ University of Amsterdam \\ Amsterdam School of Economics, University of Amsterdam \\ Valckenierstraat 65-67, 1018 XE Amsterdam, The Netherlands \\ Phone: +31 20 5254236, Fax: +31 205254254 \\ E-mail: s.zaheer@uva.nl \\ and \\ Sweder J.G. van Wijnbergen \\ University of Amsterdam and Tinbergen Institute \\ Amsterdam School of Economics, University of Amsterdam \\ Valckenierstraat 65-67, 1018 XE Amsterdam, The Netherlands \\ Phone: +31 20 5254206, Fax: +31 205254254 \\ E-mail: s.j.g.vanwijnbergen@uva.nl
}

First draft, July 2013

* Corresponding author. 


\begin{abstract}
Islamic strictures require investors to share risks with the entrepreneurs they finance. Sukuk (Islamic securities) come mostly in two varieties, musharakah (basically a joint venture agreement) and ijarah (more like an operational lease agreement). Yet defaults did happen, even in the case of musharakah (joint venture) sukuk discussed in this study. So is Islamic finance failing to deliver on its promises? To answer that question, we analyse four major defaults on Sukuk that have happened recently in the aftermath of the worldwide credit crisis that has engulfed the world since 2007. These case studies make clear that in most cases, the problems can be traced back to clauses and structures that made the sukuk more like conventional bonds. Furthermore, once default happened, most of the sukuk discussed did not transfer the underlying assets to the sukuk holders. So, in the event of default, due to limited recourse provisions, sukuk holders often had nothing to resort to, as effectively there were no underlying assets in their ownership. The case studies highlighted the importance of the legal institutions of the country where the collateral is likely to be contested. Interestingly enough, strict adherence to shariah principles would have considerably simplified restructuring because shariah compliance implies a clear allocation of property rights: in sukuk, investors will receive full title to the underlying sukuk assets in distress situations. So the answer to the question we asked, is Islamic Finance failing to deliver on its promises, is a qualified no.
\end{abstract}

Keywords: Defaults; Islamic Securities; Islamic Finance 


\section{Inroduction}

In the last few years, some major sukuk defaults raised several questions about the underlying structures and viability of the sukuk as an alternative source of funding. One notion about the sukuk is that these instruments, like equity, are profit and loss sharing (PLS), so there should be no question of default in what was intended as a (limited liability) equity-like instrument. Moreover, sukuk are publicized as securities backed by real assets. In that case, the investors should only be exposed to risk of capital loss, the risk that arises due to fluctuations in the market value of underlying assets, and of the periodic returns (rentals) generated by these assets. But normally there would be no default of the entire principal sukuk amount, as sukuk holders are presumed to have recourse to the sukuk assets, being the legal owner of those assets. Thirdly, the sukuk, advertised with a religious notion, are assumed to follow more transparent processes and contain unambiguous clauses in their main contract. Accordingly, all the documentations in sukuk issuance are supposed to contain no inconsistencies and loopholes which can deprive the sukuk investors of the rights promised in the offering circulars.

Yet, defaults did happen, and not all were resolved in line with the expectations raised by these new capital market instruments. So what went wrong? If these principles were properly followed, then why did sukuk default in first place? Or are there any structures in which sukuk may default in spite of their equity-like characteristics? What were the main reasons for sukuk defaults? And how were the distress situations resolved? Did investors have any recourse to sukuk assets and if not, why not? Why did the originators issue the sukuk instead of conventional bonds? How have sukuk been restructured after default events? Does the analysis of these distress situations and their resolution offer insights on the future of Islamic Finance? Did the defaults happen because of flaws in the basic Islamic Finance approach or on the contrary because of imperfect compliance with the principles of Islamic Finance? Can the variety of distress experiences shed light on design improvements?

The focus in this paper is on the resolution process following default, not on the reasons why the default was triggered to begin with. We analyze the recent sukuk (near) defaults from an Islamic finance perspective. Specifically, after providing basic information on each sukuk (issuer, 
arranger, SPV, term period, rate of return etc.), we present an exposition of the underlying contracts of each sukuk, their structure, reasons for defaults and restructuring process thereafter. Finally, we provide a discussion on the critical issues related to sukuk structures namely ownership of underlying sukuk assets, rights of the investors including recourse, if any, to core assets in case of distress, risk factors including legal and shariah risks regarding sukuk structures, purchase undertakings and credit enhancements. These clarifications are crucial if access to the capital markets is to be continued through sukuk. The recent turmoil in the conventional financial sector adds to the relevance of the topic.

The remainder of the paper is structured as follows. We first give a brief overview of the emergence of Islamic capital market instruments (Section 2). We then more sharply define the precise structure of the various instruments traded (Section 3). In Section 4 we present four case studies of major recent sukuk defaults and the ensuing resolution of the distress situation. Section 5 discusses the critical issues that emerge from this overview of major defaults. Section 6 concludes the paper. Basic information about four problem sukuk are provided in Table 1 in the Tables Annex. Most of the information about sukuk are acquired from the offering circular (OC) of the relevant sukuk, financial reports of the sukuk originators, related stock exchanges \& central banks, IMF reports and newspapers.

Sukuk issuance grew from zero to a cumulative USD350 billion from 1996 to mid-2012 and the issuance to surge with cumulative annual growth rate of 25\% over 2012-2015 (Standard \& Poor's 2012). The sukuk market is still in its infancy, but global issuance of Islamic capital market instruments (so-called sukuk) surged 55 percent during the first quarter of 2012 to reach USD43.5 billion (Halawi and Atamech (2012 )). In February 2013, Dubai Electricity \& Water Authority sukuk issuance was subscribed by more than $\$ 5$ billion of bids for the $\$ 1$ billion sukuk amount. ${ }^{1}$ Similarly, in last week of May 2013, sukuk issued by Islamic Development Bank for five years got $\$ 1.5$ billion in bids for $\$ 1$ billion of securities and it offers a return as low as 1.535

\footnotetext{
${ }^{1}$ http://www.bloomberg.com/news/2013-06-05/goldman-breaks-drought-with-saudi-property-bond-islamicfinance.html
} 
percent. ${ }^{2}$ Currently, Sukuk are issued by both Islamic and conventional corporate entities, financial institutions, and even sovereigns across the world.

Interestingly, the first corporate sukuk totaling USD30 million was issued by Shell, a conventional company, in 1990 after sukuk structure was approved in 1988 by the Organization of the Islamic Conference (International Islamic Financial Market (2009)). German SaxonyAnhalt was the first non-Muslim state to tap into this market: it issued 5-year sukuk to raise EUR 100 million in 2004 with AAA rating by Fitch ${ }^{3}$ (Stimpfle (2011)). Similarly, The World Bank issued its first sukuk in 2005 to raise 760 million Malaysian ringgit (RM), ${ }^{4}$ while its private sector arm, the International Finance Corporation, issued sukuk of RM 500 million in 2005 and USD100 million in 2009 (Iqbal and Tsubota, 2006). Currently, some big sukuk have been announced such as a sovereign sukuk by Ireland and Saxony-Anhalt and a corporate sukuk of USD2 billion by Goldman Sachs. ${ }^{5}$ Malaysia and Gulf Co-operation Council (GCC) countries played a leading role in sukuk issuance in the wake of economic expansion and booming oil and property prices (Boustany, Roula and Sayegh (2005 )).

Sukuk were basically designed to facilitate the liquidity management of the Islamic banking sector (Usmani 2010) which otherwise needed to keep excess reserves to mitigate liquidity risk. Sukuk also emerged as an alternative investment opportunity for those desiring to capitalize their funds according to their religious beliefs. Since pious Muslims avoid investment in interest based securities, sukuk intend to tap into their funds through a kind of debt financing that is Shariahcompliant. These instruments attracted conventional investment banks and hedge funds as well because of the asset-backed structure of sukuk and promising returns offered by these securities. From the issuers' perspective too, sukuk appeared as an innovation in the capital market instruments through which borrower can raise funds from a wider range of investors.

For sovereign issuers there can also be a cost of capital advantage in sukuk issuance because of the higher credit rating owing to their asset-backed structure and because they offer a broader and diversified global investors base (Jobst, Kunzel, Mills and Sy (2008 )). The Saxony-Anhalt ijarah sukuk, for instance, exhibits obvious price benefits of shariah-compliant sukuk issuance

\footnotetext{
${ }^{2}$ http://www.reuters.com/article/2013/05/29/saudi-isdb-sukuk-idUSL5N0EA28620130529

${ }^{3}$ The corresponding SPV was established in Netherlands to get tax benefits.

${ }^{4}$ Around USD200 million.

${ }^{5}$ Source: Bloomberg, Reuters, Zawya.
} 
over conventional bonds. In 2004, the German state borrowed USD1.2 billion through interest based covered bonds at EURIBOR plus 17 basis points on average, whereas its primary sukuk were priced at a spread of only 1 basis point, that saved USD192,000 per year for the State's Treasury (Jobst, Kunzel, Mills and Sy (2008 )).

\section{The nature and structure of Sukuk}

\subsection{What are” Sukuk”?}

Sukuk is plural of the Arabic term sakk which means certificate, legal instrument or deed. In Islamic finance, the term sukuk refers to securities backed by real assets. We outline in what follows the general sukuk structure as suggested in the theory of Islamic finance. The contemporary practice regarding sukuk issuance often strays from these principles however, as we will highlight in the four case studies presented in the next section.

\subsection{Stylized Sukuk Structure}

Sukuk are based on specific contracts borrowed from Islamic modes of financing. Article 2 of the Accounting and Auditing Organization for Islamic Financial Institutions (AAOIFI (2008)) ${ }^{6}$ defines sukuk as "certificates of equal value representing undivided shares in ownership of tangible assets, usufruct and services or (in the ownership of) the assets of particular projects or special investment activity. ”

The main difference between sukuk and conventional bonds is that sukuk do not involve any interest based transactions because of their prohibition in shariah. Like conventional assetbacked securities (ABS), sukuk are also backed by assets. However, the difference between sukuk and conventional ABS is that in the latter the underlying assets can be financial assets like loans or other receivables but in sukuk only real assets can be used as collateral. The sale of debt is not permissible in Islamic finance, except when it is traded at par. ${ }^{7}$

Although initially various structures were employed for sukuk, ijarah (similar to a conventional operational lease contract) and musharakah (joint venture/ co-ownership) have

\footnotetext{
${ }^{6}$ The AAOIFI is an Islamic international standard issuing institution that prepares accounting, auditing, governance, and shariah standards for Islamic financial industry.

${ }^{7}$ This is the viewpoint of majority of scholars. However, in Malaysia and some other countries discounted sale of debt is considered permissible.
} 
become the most popular and commonly used sukuk because of their eligibility for trading in the secondary market according to Islamic jurisprudence. Ijarah sukuk (securities based on an operating lease contract), adopt the following process. The originator company, seeking financing, establishes a special purpose vehicle (SPV), generally a trust, ${ }^{8}$ incorporated as an offshore company. Subsequently, the SPV purchases certain assets (e.g. real estate, land parcels and/or building, leasehold rights) from the originator through a transaction, ${ }^{9}$ and funds this transaction with the proceedings raised through issuing trust certificates (sukuk). Pursuant to the transaction deed, assets of the originator are transferred to the SPV (the issuer) which holds these assets as a trustee for sukuk investors following a declaration of trust. Next, through a lease agreement, the same assets are leased back to the originator, being the lessee, on which periodic rent is paid by the lessee to the sukuk holders through the SPV. There is generally a repurchase undertaking by the originator according to which the originator is obliged to buy the assets back from the SPV on maturity of sukuk or upon an event of insolvency, at the market/fair price or at a price on which both parties agree at the time of purchase. ${ }^{10}$ The repurchase agreement is independent of the main sukuk agreement. The process enables sukuk redemption and reimbursement of the amount to the sukuk holders. Subsequently, the trust is dissolved. Thus the residual asset value risk is borne by the originator who undertakes to buy the asset on market price. An important restriction on ijarah sukuk is that the return (rent) should be commensurate with value of the underlying sukuk (assets). This was an issue in the case of East Cameron Partners, to be discussed below.

Another popular sukuk structure is musharakah (joint venture/co-ownership). ${ }^{11}$ In this structure, the originator transfers the ownership of some of its assets, 50 percent for instance, to the SPV against the sukuk proceedings. A musharakah is established between the SPV and the originator in which the originator also contributes through investing funds/assets into

\footnotetext{
${ }^{8} \mathrm{An}$ SPV is created for bankruptcy remoteness by isolating the underlying assets of the transaction, for benefit of investors, from other liabilities of the originator. Thus in case of default of the originator, the investors are the sole claimants on the assets of the SPV. Some jurisdictions support SPVs by especial law. For instance, in the Cayman Islands, newly established SPV may be exempted from the taxes for 20 years (Khnifer (2010 ))

${ }^{9}$ This is, when the ijarah sukuk are asset-backed.

${ }^{10}$ This is what AAIOFI standard 12 suggests. However, market practice may be different in which originator/manager of the sukuk undertakes to buy the sukuk at their face value at the time of sukuk maturity. This strategy is declared un-Islamic by AAIOFI because this practice makes the structure of the sukuk similar to an interest bearing conventional bond.

${ }^{11}$ See (El-Hawary, Grais and Iqbal (2004)).
} 
musharakah. Accordingly musharakah assets, jointly owned by the SPV and the originator, are invested in some business and the periodic streams of income generated by these assets are shared between the sukuk holders and the originator according to a pre-specified ratio. The loss is borne by the partners proportional to their investments.

The difference between musharakah and ijarah sukuk is that in the former the sukuk holders also share the ownership of the underlying musharakah assets with the originator if the assets are used for a business whereas in ijarah, sukuk holders are the sole owner of the underlying assets. The originator acts as manager of the assets on behalf of the SPV and sukuk holders, pursuant to a management contract. Like ijarah, an undertaking to repurchase the sukuk at the market price is also made by the originator. In this way sukuk are redeemed and the trust is dissolved. Clearly in musharakah the returns may fluctuate more than in an ijarah contract when market conditions change, unless there too the musharakah assets are leased out. For this reason, the return requirement are less stringent for musharakah sukuk than they are for ijarah: for ijarah, returns on the collateral and on the sukuk should be commensurate, but for musharakah the returns paid out should offer the expected return, which may be different from the ex post return. This gives more flexibility in designing the instrument. For example, in musharakah (joint venture) the return can be lower than the expected return offered to the investors, in which case the issuer can forgo some of its share in profit and transfer it to the investors as a gift to make the mushakarah return equal to promised 'expected return' (cf the discussion of the ECP sukuk below). Both of the aforesaid sukuk types are backed by assets and are therefore called assetbacked sukuk.

There also exists another class of sukuk, the so called asset-based sukuk, where the initial sale of the original assets by the originator to the SPV does not take place, so the ownership (title) of assets remains with the originator of the sukuk. The sukuk holders are entitled to periodic cash flows from the underlying assets. An undertaking is also made by the originator to buy back the sukuk at their face value on the maturity date of sukuk. Further security can be given by providing collateral such as claims on shares of the originator, mortgages on structures owned by the originator or third party guarantees. But according to AAIOFI ((2008)) standards, such assetbased sukuk are not shariah compliant because there is no transfer of assets to the sukuk holders 
which effectively makes asset based sukuk look more like conventional bonds ${ }^{12}$. Investors in asset-based sukuk typically rely on the creditworthiness of the originator as indicated by a credit rating given by the rating agencies. Obviously, the different ownership structure may create problems regarding execution of the collateral.

\subsection{Shariah compliance: the theory}

In February 2008, the Board of AAOIFI attempted to bring order in the wide variety of products in the sukuk industry claiming to be shariah-compliant, and issued the following precise guidelines for sukuk to be in accordance with shariah principles:

1. Sukuk holders must own the real assets whether tangible, usufructs or services, capable of being owned and sold legally, with all rights and obligations of ownership, in those assets. Transfer of the assets from manager/originator is ensured by writing them off (sukuk) its books.

2. Sukuk, to be tradable, must not represent receivables or debts except in the case of a trading or financial entity selling all its assets, or a portfolio with a standing financial obligation, in which some debts, incidental to physical assets or usufruct, were included unintentionally ${ }^{13}$

3. It is not permissible for the manager of sukuk to undertake to offer loans to the sukuk holders, when actual earnings fall short of expected earnings.

4. While issuing sukuk, it is also not permissible that the manager of sukuk undertakes to repurchase the assets from the sukuk holders at initial value (face value), at the end of sukuk. However, it is permissible to repurchase the same at their market value, fair value or a price to be agreed, at the time of their actual purchase.

5. It is permissible for a lessee in an ijarah sukuk to undertake to purchase the leased assets when the sukuk are extinguished for its nominal value, provided he (lessee) is not also a partner or investment agent.

\footnotetext{
${ }^{12}$ In November 2008, AAOIFI announced that for this reason 85 percent of the sukuk issued in GCC countries did not comply to shariah rules. http://www.gulf-daily-news.com/NewsDetails.aspx?storyid=200624.

${ }^{13}$ Although Sukuk must represent tangible assets, however, If the underlying assets of a sukuk is "an entire company" then it is okay if the assets of the company includes "real assets plus receivables", because companies have receivables/payables as part of their normal business operations, so there is little choice but to allow the incidental intangibles.
} 
6. Besides issuing fatwa (shariah rulings) about the validity of sukuk structures, shariah boards should also carefully review all the relevant contracts and documents related to the sukuk transaction and make sure that the actual means of implementation, operations and investments comply with shariah standards.

\subsection{Shariah Compliance: in practice}

Since the underlying idea of sukuk is religiously motivated, it has been argued that it will lead to more prudent, ethical and responsible financing (Howladar (2009)). However, the pursuit of profit and moral hazard problems cannot be ruled out in Islamic finance either. For example, one may exploit the shariah differences among various scholars/jurisdictions by claiming that a contract is against shariah, only to avoid one's obligations as a borrower. In some cases, debtors in distress have questioned the shariah compliance of the underlying contract and challenged contractual obligations on that basis. In two such instances, lawsuits about murabahah transactions were filed by Symphony Gems NV and Beximco Pharmaceuticals. In both cases however, English courts passed judgments against debtors of Islamic banks who claimed that their contracts effectively implied charging interest which is prohibited in Islam and thus should be cancelled. In both cases however, the courts allowed Islamic banks to collect accumulated interest (El-Gamal (2007)).

However there are also verdicts that seem to go in a different direction. In one case, Blom Bank of Lebanon placed its funds with TID as the bank's agent (wakeel), to invest the funds in some profitable venture. The wakalah (agency) agreement had an equity-like nature for investors, but since TID issued a promissory note ensuring principal amount and return (interest) on the investment, the contract de facto became an interest based conventional loan contract. When TID defaulted, it appealed in the English court to consider promissory note as void because it was against the wakalah contract and thus not allowed under shariah. The court delayed the case for detailed deliberation regarding the payment of return. However, the principal amount had to be paid by TID (see Hasan and Asutay (2011) for details on courts' decisions in Islamic finance). 


\subsection{Performance in distress situations: Investor Rights and Legal Risks}

From the point of view of Islamic law, if a debtor defaults due to "natural factors" s/he should be given the opportunity to pay the debt when possible. Also if the debtor is not able to repay at all, the lender is encouraged to write off (discharge) the debt. But if the loan is backed by assets as security, the debt can be liquidated to recover the principal amount.

In the case of asset-backed ijarah and musharakah sukuk, the certificate holders have recourse to the underlying assets in the event of default provided that all the legal arrangements required to become a genuine owner of the assets are put in place. Thus the risk faced by the investors is at most the risk of capital loss due to a decline in the prices of underlying assets (market risk) and/or default of the lessee on rental payments. There are other risks involved in acquiring complete recourse to the sukuk assets namely, legal risks and risks related to the enforceability of the court ruling. Generally, sukuk are governed by the English law, but final recourse to the underlying asset unavoidably will depend on the law of the jurisdiction in which assets are located. The local courts may not allow recourse to the sukuk assets pursuant to any judgment of the English courts, thereby exposing investors to legal risk. Also, even if the law allows for the recourse, it may nevertheless not be applied because of the public policy of the concerned state about ownership of the assets (Ryan and Elmalki (2010)).

On the other hand, if the sukuk are asset-based, in which case sukuk assets are not transferred to the sukuk investors, there can be no question of recourse to any assets. Therefore, in the event of default of the originator, sukuk are given the status of unsecured debt subordinated to the originator's other obligations. Usually, in the event of default, sukuk holders can use their rights they acquire through repurchase undertaking by the issuer and ask the issuer to repurchase the sukuk. Moreover, if any other collateral has been given to the sukuk holders, for example in the form of a mortgage, claim on shares or lien, those can be called in to recover the sukuk investment. Furthermore, if there is any third party guarantee in the sukuk issuance, the guarantor can be approached, if necessary, through litigation. In practice however, and against the shariah principles, when sukuk defaulted, the investors were unable to have recourse to the issuers' (sukuk) assets as the assets were not transferred to the investors (International Islamic Financial Market (2009)). 


\subsection{Performance in distress situations: Restructuring}

Although sukuk holders can go for litigation, they may instead prefer to enter into some sort of settlement through restructuring of the sukuk instead. Shariah also recognizes the concept in case the borrower/obligor is financial distress. Restructuring can be implemented in various ways: through extending the time period for repayment of sukuk investment, through recovering partial payments from the originators, thus incurring some loss (McMillen (2011 )) or by actually writing off the entire loan. The bargaining power of the parties depends upon the validity of their claims recognized in transaction documents, recourse to sukuk assets, undertakings, securities and enforcement of the court's judgment. The regulatory authorities of the jurisdiction in which the originator is based also play active role as the default event can have a contagion effect due to financial sector exposure to the sukuk. Therefore, for instance, the central bank may intervene into restructuring and resolution processes, as was done by the Saudi Monetary Authority (SAMA) in the case of Saad sukuk. Also, there is an instance in which the issuer (Dubai Islamic Bank), called back a portion of its sukuk offering at 88percent of the face value. However the offer was not well received: less than 50 percent was eventually bought back (International Islamic Financial Market (2009)).

\section{Prime Sukuk Defaults: 4 Case Studies}

In developing the structure of sukuk, most attention was paid to making the financial instrument interest-free. Investors' expectations about possible sukuk defaults were rare, particularly when they were issued by state-owned companies. Although several risk factors were described in most of the sukuk offering letters, possible consequences in the event of default were given less consideration by the investors and even by scholars of shariah (Islamic law) who initially approved the product (Warde (2011)). But then the global financial crisis hit the economy in the regions where sukuk issuers operated, and some very visible sukuk defaulted on periodic payments in 2009. In 2008-2009, Islamic banking and capital markets were also affected adversely. There were some major events of sukuk defaults in the US and Gulf Cooperation Council (GCC) states. The first sukuk default occurred on October 16, 2008 when East Cameron 
Partners (ECP), a US oil and gas company, filed for bankruptcy protection under chapter $11{ }^{14}$ claiming its inability to pay the periodic returns on its USD166 million sukuk issued in June 2006. Subsequently, the first sukuk default in the Gulf region occurred on May 12, 2009 when Investment Dar, a Kuwaiti Islamic investment company, declared its failure to pay biannual return on its USD100 million sukuk (Anwar and Patterson (2009 )). Just few weeks after, Saad Group, a Saudi conglomerate failed to pay periodic rental payments on its USD650 million sukuk, issued 2007. Next, in the last week of November 2009, the Government of Dubai announced a standstill for 6 months for all its debts, including the largest Nahkeel sukuk of USD3.5 billion just few weeks before sukuk maturity. The default was prevented eleventh hour by the Abu Dhabi state through a USD10 billion bailout package. In what follows, we discuss these four cases in detail and the issues that emerged following the defaults.

\subsection{East Cameron Partners’'Sukuk Al-Musharakah}

East Cameron Partners (ECP) issued sukuk of USD165.67 million in July 2006 with maturity period of 13 years. ${ }^{15}$ This was the first sukuk issued by a company based in United States and rated by Standard \& Poor's. The underlying contract was musharakah (co-ownership/joint venture) in which sukuk investors own so called Overriding Royalty Interest (ORRI) ${ }^{16}$ in two gas properties located in the shallow waters offshore the State of Louisiana through an SPV acting as a trustee of sukuk holders. The SPV was called East Cameron Gac Company (ECGP) and incorporated in the Cayman Islands. The originator also contributed its funds into the musharakah. The assets of the musharakah were co-owned by the sukuk holders and the originator company ECP. The sukuk were secured by a mortgage on the assets of the issuer, which included the ORRI and secured accounts. The sukuk were rated CCC+ by Standard \& Poor's.

\footnotetext{
${ }^{14}$ Chapter 11 of the United States' Bankruptcy Code allows restructuring of the problem entity under the bankruptcy laws of the US. http://en.wikipedia.org/wiki/Chapter_11,_Title_11,_United_States_Code

${ }^{15}$ The main sources for the sukuk are East Cameron Gas Co. Past-Closing Presentation and IFR 2006.

16 According to Louisiana law, de facto the law governing oil and gas leases, ORRI are considered 'real property’. http://www.zawya.com/blogs/blakegoud/090215215223/
} 
The Originator's Details and Purpose of Sukuk Issuance

ECP was incorporated in Houston, Texas as a private oil and gas exploration company in 2002 and acquired leasehold interests in oil and gas production, in federal oil and gas leases administered by Minerals and Management Services of the US Department of Interior (MMS)(Boustany (2006)). The purpose of the originator was not shariah compliant financing per se. ECP simply saw this as an affordable and flexible finance opportunity through which it could raise the funds needed to purchase of shares from its non-operating partner, Macquarie Bank who wished to sell its share in the business. Finding limited opportunities in conventional finance, the owner of the company judged issuing sukuk a better choice.

\section{ECP's Sukuk Structure}

The original plan was to issue an Ijarah (leasing) sukuk, but the return on the assets to be financed through the sukuk issue were not commensurate with the sukuk return deemed necessary for a successful placement of the sukuk. Therefore, the sukuk was structured as musharakah, which allowed ECP to pay a higher return on the sukuk than the return on the shares whose purchase was to be financed through the sukuk. The difference between equity shareholding and musharakah sukuk is that the sukuk are redeemable within some time period as well as have limited recourse to underlying musharakah assets. ECP presumably was willing to pay a premium return to its financiers because through this transaction it would get complete control of the shares after expiration of the sukuk. Ijarah sukuk would not have allowed such a financial structure.

The structure of the sukuk works as follows (see Figure 1):

1. The issuer SPV, East Cameron Gas Company (ECGP), incorporated in Cayman Islands issued USD165.7 million of sukuk whose proceeds would be used to buy the ORRI from the Purchaser SPV following a Funding Agreement for USD\$ 113.8 million. The remaining amount was appropriated for development plan, a reserve account and the purchase of put options for natural gas to hedge against the risk of fall in gas prices.

2. The originator contributed his share of the capital in the form of a transfer of ORRI into the purchaser SPV.

3. Next, the purchaser SPV, holding ORRI in the properties, would be entitled to around 90 percent of ECP's net revenue generated though gas production. 
4. The production would be sold to two off-takers with Merill Lynch as a backup off-taker.

5. Proceedings of the oil and gas sale would be transferred to an allocation account. After paying around 20 percent to government and private ORRI, the remaining amount would be transferred to the Purchaser SPV. Next, the purchaser SPV would allocate 10 percent for the originator and the remainder for payment of expenses, periodic sukuk returns and redemption amount. Any excess amount would go to originator and early redemption of the sukuk equally.

6. Upon maturity of sukuk, the issuer SPV would redeem all the sukuk against the amount left to be transferred to the sukuk holders. 
Figure 1, Panel A: Transaction Schematic

The repayment of the sukuk was

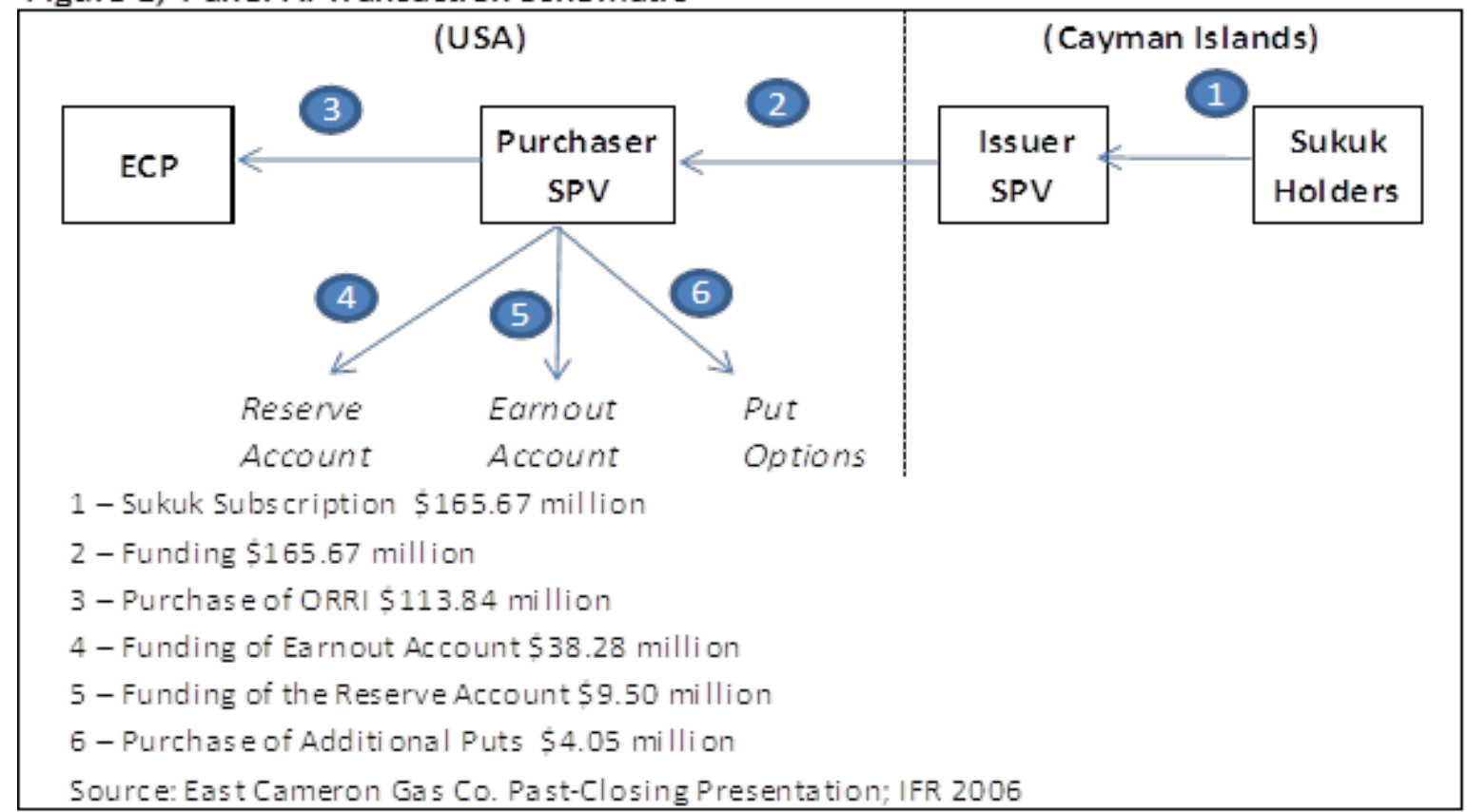

Figure 1, Panel B

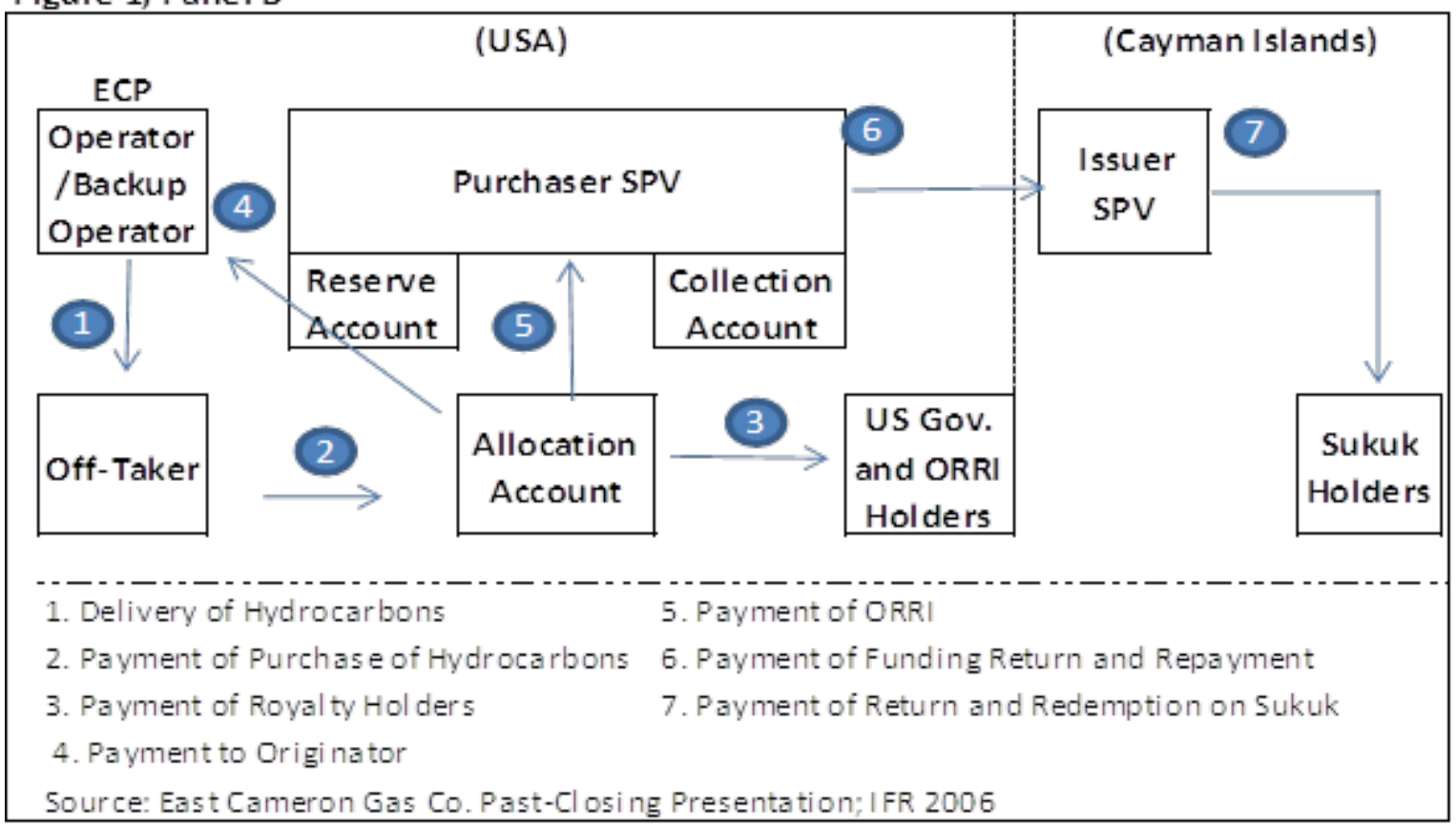

scheduled quarterly depending upon the production and sale of the hydrocarbons to the buyers. An expected return of 11.25 percent was offered to the sukuk investors, to be paid quarterly too. A reserve account was also maintained as a credit enhancement, dedicated to meet any shortfall 
in return with the moneys reserved in the account. Furthermore, put options were bought to acquire the right to sell the oil and gas at the strike price, thereby providing a hedge against a falloff gas prices below the strike price.

\section{Shariah compliance of the ECP Sukuk}

Of the four cases discussed in this section, only the ECP sukuk can be considered as an asset backed sukuk and only that structure fulfills (most of) the requirements of shariah principles described by AAOIFI (2008).

\section{- Ownership of the Musharakah Assets}

The sukuk holders were declared as the owners of underlying assets which are claims on oil and gas reserves through registered ownership of ORRI and which are deemed as real property in the related jurisdiction.

\section{- $\quad$ Credit Enhancements}

Credit Enhancement was provided through an USD9.5 million reserve account which is in accordance with the shariah principles mentioned by AAOIFI 2008.

\section{- Put Option}

Although Sukuk structure use conservative commodity price projections there could be fluctuations in the oil and gas market price. To mitigate downside price risk, commodity price hedges are often put in place. Moreover, a backup offtake agreement was made with Merril Lynch to hedge the risks related to demand for gas production.

\section{Restructuring the ECP Sukuk}

ECP, the originator company, defaulted on periodic payments to the sukuk holders not because of low prices but due to financial problems arising from the shortfall in oil and gas production triggered by damage after a Hurricane in the area in September 2008. ${ }^{17}$. On 16 October 2008, East Cameron Partners, the originator, filed a petition for bankruptcy protection under chapter 11

17 The United States Securities and Exchange Commission report (Form 10-K) annual report 2008 http://www.wikinvest.com/stock/TEL_Offshore_Trust_(TELOZ)/Filing/10-K/2009/F3243816 
of the United States Bankruptcy Code in the United States Bankruptcy Court in Louisiana to reorganize their debts and operations.

Also, ECP filed 'adversary proceedings' and requested the court to consider the primary sukuk transaction with the purchaser SPV as 'secured loans' and not as 'true sale' of assets (McMillen (2011)). This would imply that sukuk holders were to share the assets with other creditors of the originator in liquidation process if the transaction is considered secured loan. The bankruptcy court apparently rejected East Cameron’s argument saying that “ [sukuk] holders invested in the sukuk certificates in reliance on the characterisation of the transfer of the royalty interest as a true sale” (Fidler (2009)). This was a very important precedent about protection of sukuk holders' rights and would subsequently have a positive impact on sukuk growth in US since it set the precedent that asset backed sukuk are in fact bankruptcy proof, the transfer of assets to the Sukuk SPV was shown to be safe from bankruptcy of the originator company.

Then, East Cameron Partners filed a revised lawsuit but, subsequently the stakeholders preferred to resolve the case through negotiations. Finally, the underlying sukuk assets were transferred to the issuer for the benefit of sukuk investors. According to the terms of the sale the assets of East Cameron Partners were sold to the Sukuk investors (Latham and Watkins (2011)). But the originator was given a subordinated ORRI on future production, which would contain some value once the principal amount of sukuk holders have been repaid. In a sense the originator received a call option on its own assets with as strike price the the principal amount of the sukuk.

Thus in the US, sukuk holders' rights are protected due to a well-developed legal system of collateral and recognition of all the contracts by the courts of law. Then situation in the GCC countries turned out to be very different, as will become clear from some of the other case studies.

\subsection{Musharakah Sukuk of Investment Dar Company (TID)}

The first sukuk default in the Gulf region occurred on May 12, 2009, when Investment Dar (TID), a Kuwaiti Holding Company, failed to make the periodic payments on a USD100 million sukuk. Subsequently, the holding company went through a restructuring process because

of its inability to service its debt of around USD3.5 billion, including two Sukuk for a total of 
USD250 million sukuk ${ }^{18}$. The first Musharakah sukuk of USD100 million was issued October 27, 2005 for 5 years. This sukuk was registered on Bahraini and London stock exchanges. In 2006 TID issued another five-year Musharakah sukuk for an amount of \$150 million. The company effectively defaulted on the second sukuk as well: shortly after the default on the first sukuk, the company entered into a restructuring process and demanded a standstill on all its debt for a temporary period.

\section{Originator Details}

TID was established as an Islamic investment company in 1994 with KD 22.8 million (USD83.3 million) capital and started its activities in accordance with the shariah. The company was registered with the Central Bank of Kuwait in August 1995 as an investment company and its shares were listed on the Kuwait Stock Exchange in April 1999. Within ten years, the company became a large lucrative holding company, offering Islamic services in consumer financing, portfolio- and funds management, Islamic banking and insurance, corporate and residential property development and logistics. In 2005 it still made a profit, of KD80.5 million, more than a threefold increase over the previous financial year, whilst total assets and equity were KD669.6 million and KD177 million, respectively. About 50 percent of its income is coming from investment activities while some 32 percent came from real estate; the rest was generated by financing activities. TID acquired a 50 percent stake in Aston Martin Lagonda Ltd, a luxury car company, in 2007.

\section{The structure of the TID Sukuk}

The first 5-year musharakah (co-ownership) sukuk was issued by TID with the collaboration of ABC Islamic Bank (Bahrain) in 2005. It offered 6-month LIBOR plus 2\% annual, whereas the 2006 sukuk issue promised LIBOR plus 1.25 percent for the first 3 years and LIBOR plus 1.75 percent for the rest of the time period, distributed semi-annually. The Sukuk issued in 2005 was registered on the Bahraini Stock Exchange while the 2006 sukuk issue was registered in Dubai International Financial Exchanges. Both the sukuk issues were structured as musharakah.

We have been unable to obtain the details of the first Sukuk emission, the one that took place in 2005. The details of the sukuk structure issued in 2006 is provided in Figure 2. Initially, an

\footnotetext{
18 The two sukuk issues were made in 2005 and 2006, for amounts of USD100 million and USD150 million respectively, both based on Musharakah (co-ownership/joint venture) contract.
} 
SPV, TID Global Sukuk I Limited, was established in the Cayman Islands. Next, sukuk are issued by the SPV to sukuk investors, initially against the proceeds of the sukuk. In step 2, pursuant to a Trust Agreement with sukuk holders, the SPV entered into a musharakah/joint venture through Musharakah Agreement, in which the SPV invested the proceeds of the sukuk to hold 48.78 of musharakah capital. Simultaneously, the originator, TID, contributed its share by transferring 'all rights, benefits and entitlements to the TID vehicles and property' to musharakah, valued at $\$ 157.5$ million valuation as indicated by a third party and agreed by the partners, thereby acquiring the remaining 52.22 percent of capital in musharakah. The total amount of capital, USD305.7 million, was invested in the motor vehicles and in property assets.

The musharakah assets were converted into 150 units, in which TID acquired 76.83 units and the issuer held 73.17 units. In step three, returns on the underlying assets were to be shared between the SPV and TID. SPV's share was to be transferred to the sukuk holders every six months. As additional security for the investment, the originator also provided an undertaking to repurchase the SPV share in the underlying assets at the end of sukuk period or upon any earlier insolvency event. Pursuant to a Management Agreement between the originator and the SPV, management of the musharakah would be carried out by the originator, charging a management fee and an 'incentive fee', if the musharakah accounts would show a net profit during a given period. The structure of the sukuk was approved by the shariah boards of both the partners. 
Figure 2: Structure of Musharakah Sukuk (TID Global Sukuk I)

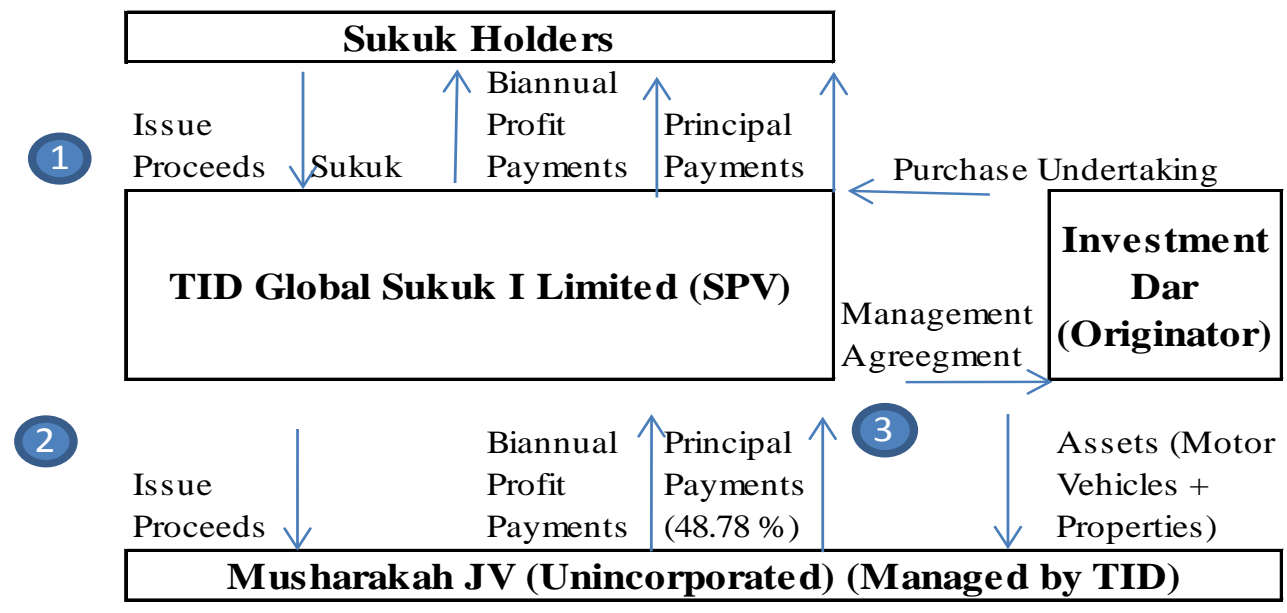

Shariah compliance of the TID Sukuk

- $\quad$ profit distribution rules

The very first page of the preliminary OC of the sukuk states that the issuer would make a payment of periodic distribution profit amounts to sukuk holders equal to LIBOR plus 1.25percent annually for the first three years and LIBOR plus 1.75percent per annum (called generally LIBOR plus margin) for the rest of the sukuk period. Further, the same document (p. 3) mentions that in return for the management services, TID is entitled to 'incentive fees' if, at the end of an accounting period musharakah accounts show a net cash profit payable to the issuer greater than the periodic distribution profit (LIBOR plus 'margin') amount. This is contrary to the shariah injunctions as the musharakah contract always offers a return subject to the actual performance of the musharakah proportional to the investors shareholding (El-Hawary, Grais and Iqbal (2004 )). According to aforesaid statement, TID is entitled to two returns, a fixed LIBOR plus margin and the amount over and above the periodic distribution profit amount as an incentive fee. Conversely, section 2.9 of Musharakah Agreement states (p. 3) that, "Each Partner shall be entitled to share in the profits of the Muskahara, and bear losses in respect of the Musharaka" proportional to their investments in total musharakah assets. This specifies that sukuk holders have to share profit or loss with the originator/obligor company. The musharakah assets may generate a fixed return, if the same leased out for instance, nevertheless musharakah 
sukuk cannot guarantee a fix return on sukuk ex-ante. However, only an expected, return can be offered to the investors, as was done in the ECP sukuk.

\section{- Accounting treatment of the sukuk amount.}

The total sukuk amount of the two issuance was KD 350 million. ${ }^{19}$ When calculating the total debt of the company in the consolidated balance sheet of 2008, TID sukuk were treated as debt in the annual accounts. The consolidated income statement and its details of revenues do not show the management fees expected from the musharakah management and the profits of the musharakah separately. According to musharakah sukuk (2006), TID is majority owner of the total assets of musharakah. Therefore, it can be argued that the musharakah accounts should be consolidated in the balance sheet of TID associates, like its other associates in which it has majority stakes.

\section{Reasons for Default}

Until 2007, business conditions for TID, the originator of the musharakah sukuk, remained good; the holding company earned a KD132 million net profit in that year, with total assets touching KD 1.27 billion assets against KD 387 million owners' equity. But in (financial year) 2008, TID reported a net loss of KD 80. 3 million, for the first time since its inception. The company's consolidated income statement shows this was for two reasons. First, there were unrealized losses of KD 88.14 million owing to impairment in the value of investments in associates ( $\mathrm{KD} 61.6$ million), ${ }^{20}$ funds placed in financial institutions (KD 12.1 million), receivables (KD 8.2 million) and impairment in goodwill. And second, there were actually realized losses of about KD 9.3 million on investments, which in the end caused the downfall of the company.

\footnotetext{
${ }^{19}$ However, the amount due to the sukuk holders was KD 10.7 million and 39.9 million for the first (2005) and the second (2006) sukuk issue respectively.

${ }^{20}$ These are Boubyan Bank K.S.C., Bahrain Islamic Bank B.S.C., AI Dar National Real Estate K.S.C.C., Safwan General Trading Company K.S.C.C. Some loss in one associate was occurred due to the a disputed repurchase transaction by TID with a Commercial Bank of Kuwait (CBK) in which TID transferred its shares in Bouyan Bank (BB), its associate, to CBK for its advisory services to TID. However, due to termination of advisory services by CBK, TID revoked the repo agreement but CBK settled the shares of KD 94 million against its debts payable by TID of KD 74.6 million. Accordingly, TID filed a lawsuit against CBK in 2009 but still the case is in the Kuwaiti court. http://www.reuters.com/article/2012/06/20/boubyan-nbk-idUSL5E8HK4XU20120620
} 
And so in October 2008, TID defaulted on its debt obligations because of acute liquidity problems; its short term liabilities significantly exceeded its liquid assets. In January 2009, the TID engaged a financial advisor to execute a debt restructuring plan. Total assets of TID and its owners' equity had decreased to KD 1.2 billion and KD 168.5 million respectively.

The company in the end went under crisis because of the high concentration of investments in related parties, clearly exceeding ' the credit concentration limit stipulated by the Central Bank of Kuwait. ${ }^{\text {,2 }}$ Auditors showed their apprehension about the ability of one of TID’s associates, The Investment Dar Bank Bahrain BSC, to continue as a going concern due to the "difficulties in recovering significant balances placed with the Parent Company [TID] and its related entities and court cases filed by investors.” The bank placed a large amount, KD 253 million, in its parent company on an unsecured basis, leading to a further increase in concentration risk. Further, the report shows that the ability of another associate of TID, involved in property development in the UK, to meet capital commitments, was contingent on its ability to get enough external finances/liquidity. All the debts as of 31 December 2008 of that associate were secured through pledging its assets to the banks as collateral.

In 2009, the company observed a second year of net losses, equal to KD 15 million, due to further as yet unrealized losses on the value of the company's assets. The assets of the company declined further to KD 971 million against total liabilities KD 766 million. The company had to make further provisions in 2009 for another KD 118 million. Trading in Dar's shares was suspended on Kuwait Stock Exchange in April 2009, when the company could not submit its financial statements on time.

\section{Restructuring}

In January 2009, the TID hired Credit Suisse Group AG as a financial advisor for restructuring TID’s debt obligations. In September 2009, TID made an agreement with its creditors and investors to freeze claims temporarily till the end of the year which was subsequently extended by TID till 31 March 2010. Meanwhile, in September 2009, the Central Bank of Kuwait appointed a supervisor to monitor the debt restructuring and more in general the

\footnotetext{
${ }^{21}$ Auditors' report of consolidated Financial Statements of 2008.
} 
company's financial accounts. TID needed to borrow around USD1 billion to refinance its debt obligations. In March 2010, a Kuwaiti court granted protection to TID from creditors under the Financial Stability Law (FSL) ${ }^{22}$. This FSL stipulates that no lawsuit or execution of any court judgment against TID from minority banks and investors would proceed until the court has approved it. In January 2011, an enhanced restructuring plan was approved both by the creditors' coordinating committee and also approved by the shareholders. The plan, effective from June 2011, included repayment of the debt in tranches of senior facility (KD 405 million payable in 34 years) and junior facility (KD 600 million payable in 6 years). Also some part of the debt was converted into equity in the company. Besides, injection of fresh liquidity up to KD 20 million had to be made by shareholders in a year.

\section{Payments}

The first payment of KD 82 million was made to the creditors two months ahead of the scheduled time of end year 2011.

\subsection{Golden Belt 1(Saad) Ijarah Sukuk ${ }^{23}$}

The third sukuk default happened on June 2, 2009 when a Saudi business conglomerate defaulted on periodic payments. Subsequently, Moody's downgraded the rating of the company to junk status. Some Gulf banks were affected severely by the Saad sukuk default because of their exposure to the heavily indebted Saudi conglomerates Saad Group and Ahmad Hamad Al Gosaibi and Brothers. ${ }^{24}$

The USD650 million Ijarah (leasing) sukuk was issued on May 15, 2007 for five years maturing on May 15, 2012 and offered an annual return of LIBOR plus 0.85 percent. The corporation issued sukuk to finance investments and property purchases in London and Saudi Arabia.

\footnotetext{
${ }^{22}$ Kuwait's FSL was approved in 2009 to support to investment sector of the country during the global economic crisis by offering liquidity and resources to restructure strong companies in the business.

${ }^{23}$ Main source for the sukuk details is the official circular of sukuk, available at http://ae.zawya.com/researchreports/p_2006_10_19_10_26_01/20080226_p_2006_10_19_10_26_01_113805.pdf

${ }^{24}$ Abu Dhabi Commercial Bank (ADCB) had around USD600 million exposure on two Saudi conglomerates, for which extra provisions had to be made. The Central banks of Saudi Arabia and UAE directed banks to make provisions on their exposure to Saad and Algosabi companies (Reuters).
} 
Saad Sukuk Structure:

The sukuk structure is based on lease and sublease contracts (figure 3). The transaction worked as follows:

1. Pursuant to a Head Lease Agreement, Golden Belt 1 Sukuk Company, an SPV registered in the Kingdom of Bahrain, entered into a long Head Lease Agreement with the chairman of Saad (Saad Trading Contracting \& Financial Services Company), in which the SPV, as head lessee, acquires certain land parcels on lease from the Head Lessor, $\mathrm{Mr}$ Al-Sanea, for 25 years. The net proceeds of the sukuk would be used to pay the total rental amount due in advance by the issuer/head lessee to the head lessor.

2. Golden Belt 1 issues sukuk of USD650 million against the leasehold rights on the land parcels and pays full rental payment upfront to owner of Saad Group (Figure 3).

3. Subsequently, pursuant to a Sub-Lease Agreement, Golden Belt 1 sub-leases the land parcels to Saad for five years against semi-annual rental payments at LIBOR plus 0.85 percent margin, the same return as paid out on the Sukuk, since this was an Ijara contract..

4. Saad transfers semi-annual rental amounts to the SPV at the promised rate.

5. SPV transfers the periodic rental amount to the sukuk holders.

6. Upon maturity when sukuk are redeemed by the sukuk holders, Saad transfers the sukuk amount to the SPV.

7. The SPV pays out the sukuk amount to the investors.

Also, initially, Saad entered into a service agreement with the owner of the Saad and the SPV in which Saad provides certain services regarding land parcels. The service fee charged from the SPV was deducted from the rental payments paid to the SPV by the Saad. Whereas, fee paid by the chairman of Saad to Saad was equal to the initial amount raised from sukuk holders ,i.e., USD650. With this technique Saad becomes able to pay the sukuk amount to the SPV at redemption of the sukuk. 


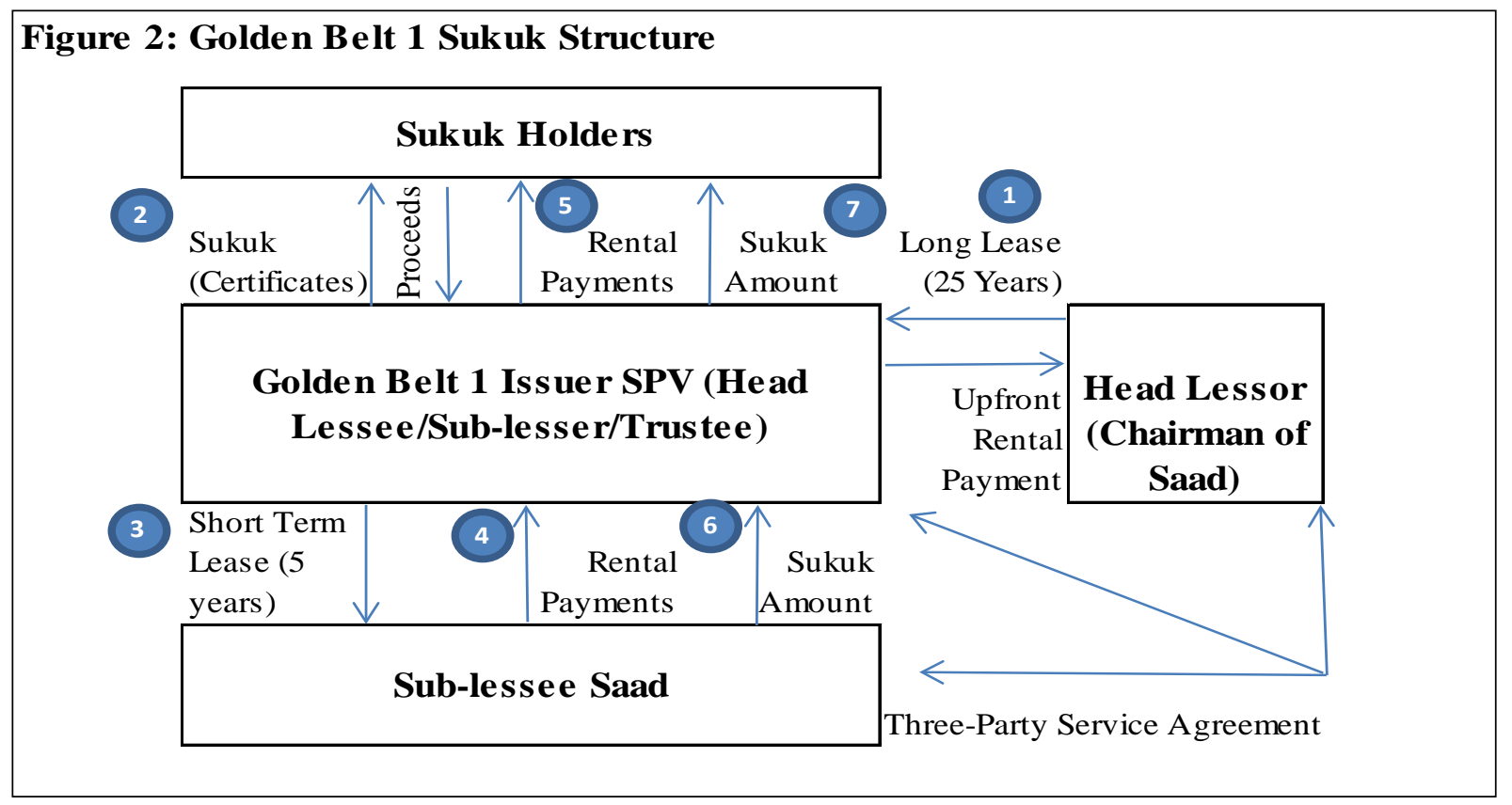

Shariah compliance of the Saad Sukuk

\section{- Promissory Notes}

To secure the sukuk holders investment and return, Saad also provides promissory notes for each payable rental promissory note and for sukuk principle amount. This feature of the sukuk treats sukuk holders equal to the general creditors in case of Saad's default as the promissory notes are governed by the Saudi law.

\section{- Dissolution Event}

If the sub-lessee, Saad, defaults on any of its periodic rental payments or, inter alia, some violation of contracts, the trust can be dissolved on the issuers request provided that sukuk holders of at least 25 percent of total sukuk amount approved the dissolution event. Upon such event, sukuk become due and repayable at face value by the sub-lessee on requested date. However, the repayment of the sukuk depends upon the financial capacity of the obligor. 


\section{- $\quad$ Risk Related to Sukuk Returns.}

Return on sukuk is offered at LIBOR plus a margin of 0.85 percent earned from the trust assets as "the sole source of payments on the Certificates." 25 Primarily, the return on the sukuk is coming from rental amounts of the sub-lessee Saad, pursuant to the sublease agreement ${ }^{26}$. However, according to sukuk OC, the determination of the rental amount is not related to the actual value of properties and thus can be challenged by the sub-lessee in Saudi Islamic courts on the equity and fairness principles. This risk is mitigated through issuance of a payable rental promissory note in favor of sub-lessor by Saad.

\section{Reasons for Default}

The Saad company defaulted on USD15.7 billion, including its Islamic bonds. The company faced a severe liquidity crisis in early 2008 and could not meet its debt service obligations on time. The originator company was singularly intransparent; proper information was not even provided to the regulators (S\&P (2009)). Because of that, the Saudi Arabian Monetary Authority (SAMA) froze the assets of the Saad group in May 2009. Also, corruption and fraud charges of USD10 billion were filed against a Maan al-Sanea, the head lessor and owner of Saad, for misusing the funds of Algosaibi Investment Holding company, the formal owner of the SPV. ${ }^{27}$ Accordingly, accounts of the Saad in Cayman Islands, valued at around USD9.2 billion, were frozen by the local courts in November $2009 .^{28}$

\section{Restructuring}

On May 18 2010, the sukuk holders exercised their right to dissolve the trust and voted for dissolution $^{29}$. However, there were legal issues which needed to be resolved before the sukuk investors were even given the status of unsecured creditors of the Saad. Upon dissolution of the trust, Saad, the guarantor of the repayment of the sukuk would have to repay the sukuk amount of USD650 million, but its assets were frozen. The litigation has dragged on for three years but the

\footnotetext{
${ }^{25}$ For instance, six month LIBOR rate in December 2007 was 4.91 percent (Fannie Mae). So for that period total sukuk return amount USD0.187 million for the six months.

${ }^{26}$ Payable Rental Amount= Sukuk Return (LIBOR+ Margin) + fixed service charges (called Supplement Return)

27 Algosaibi Investment Holding company, formal owner of the issuer SPV with nominal capital of Bahraini Dinar 1000 .

28 http://www.bloomberg.com/news/2011-11-09/saudi-arabia-s-algosaibi-wins-cayman-judgment-against-alsanea.html

${ }^{29}$ http://www.zawya.com/story/Golden_Belt_sukuk_holders_approve_dissolution-ZAWYA20100518100453/
} 
case is still in Saudi Courts. In April 2012, of Citicorp Trustee Company Limited, the agent of the issuer of the sukuk, communicated that legal proceeding were still in progress and there were issues that still needed to be resolved. On May 28, 2012, the agent informed the sukuk holders about the hearing before the Commission for the Settlement of Negotiable Instruments Disputes (CSNID) in the Kingdom of Saudi Arabia on 28 May 2012 in which the defendant (Saad) demanded that the original promissory note be submitted to the CSNID, and that previously provided promissory note was not genuine as the signature on the copy was not of MR AlSanea. ${ }^{30}$ Clearly, this structure was not bankruptcy proof.

\subsection{The Nahkeel Sukuk}

The Nahkeel sukuk was Dubai-based, high profile and the largest ever. It was issued on December, 142006 for a period of 3 years maturing on 15 December 2009 to raise USD3.5 billion. The sukuk were listed on the Dubai International Financial Exchange. The main objective of the sukuk was to finance a property development project of one of the public sector enterprises of Dubai, Nahkeel Co. PJSC. For this purpose, a special purpose vehicle (SPV), Nahkeel Development Limited, was incorporated with limited liability in the Jebel Ali Free Zone. The originator, Nahkeel Holdings 1, was a subsidiary of Nahkeel World, which, in turn, was owned by another public sector company, Dubai World. Nahkeel Holdings 1, Nahkeel Holdings 2 and Nahkeel Holdings 3 hold cumulative shares of 100 percent in Nahkeel Co. PSJS. Therefore, since they were issued by a public sector enterprise, the sukuk were given the status of a sovereign bond by the rating agency: investors assumed an implicit government guarantee for the sukuk. This is also clear by the high ratings given to the sukuk by Moody’s (A1) and Standard \& Poor's $(\mathrm{A}+)$.

\section{The Structure of the Nakheel sukuk}

The Nahkeel sukuk were issued as asset based Ijarah manfaa (Salah (2010)) in which sukuk holders, via an SPV, buy the leasehold interest of the primary assets without transferring the title of the assets to them. Therefore, Sukuk holders only had rights on the stream of income generate by the assets and not on the assets themselves.

In Nahkeel Sukuk the structure was as follows (see Figure 4)

\footnotetext{
${ }^{30}$ http://static.mubasher.info/File.Story_File/SUKUK_20120603_PR.pdf
} 
1. Nahkeel Development, an SPV, issues Nahkeel sukuk to raise USD3.5 billion to purchase the leasehold interest/rights in certain land, building and other property at the Dubai Waterfront, valued at AED 15.5 billion dated October 31, 2006 by Jone Lang Lassalle.

2. The SPV transfers the proceeds of the sukuk to Nahkeel holding 1 and purchases leasehold rights of the underlying properties from Nahkeel Holding 1, for 50 years.

3. Further, the SPV, as a trustee of sukuk holders, leases the underlying sukuk assets to Nahkeel Holding 2 for a period of 3 years. Half of the lease amount is paid to sukuk holders via the SPV and the other half is deferred till maturity of the sukuk.

4. The lessee, Nahkeel Holding 2, also makes a unilateral undertaking to purchase the leasehold rights from the SPV upon maturing of the lease period at certain price and with payment of the other half of the rental payments.

\section{Figure 4: Structure of Nakheel Sukuk}

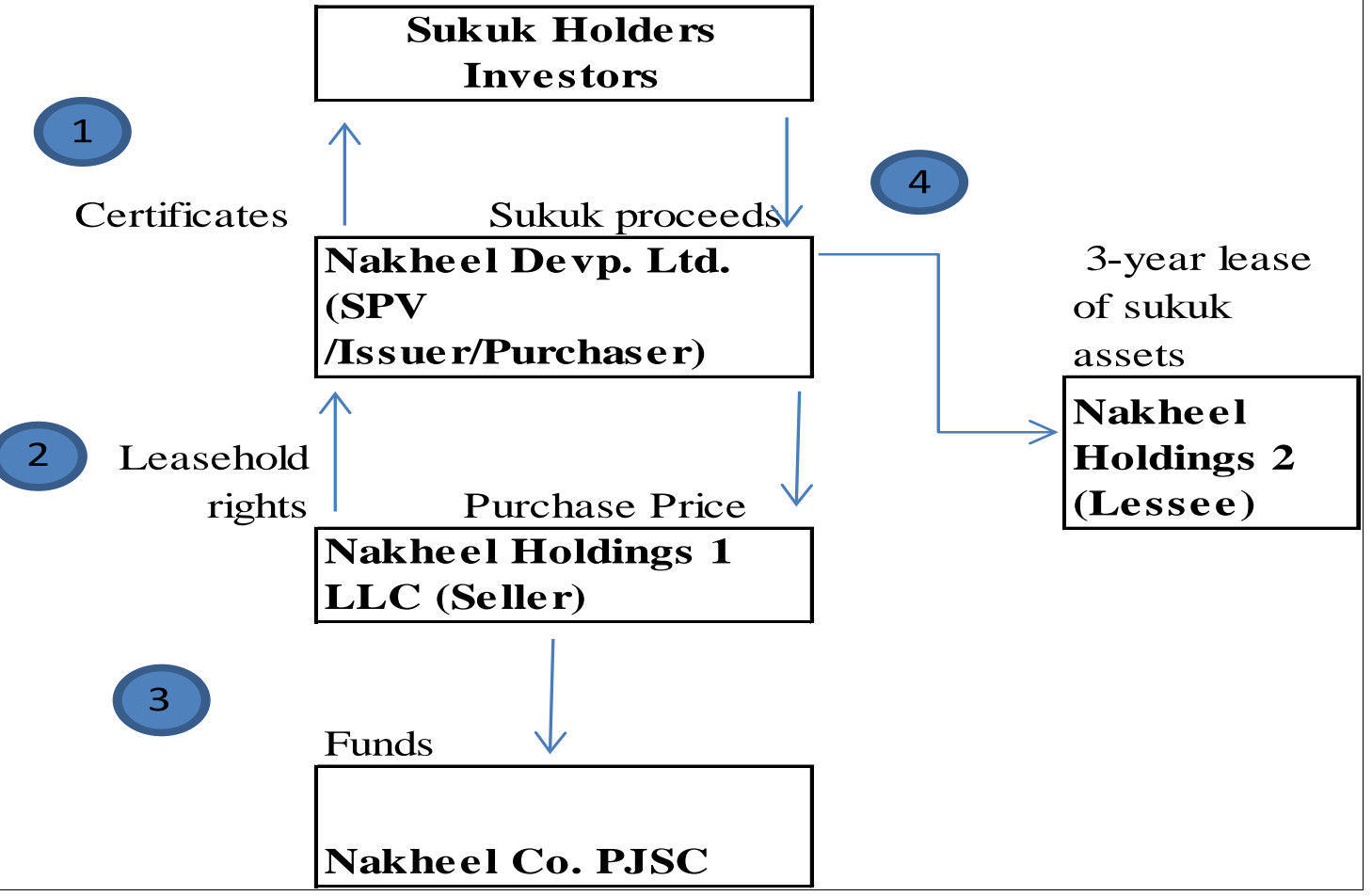

Shariah compliance of the Nahkeel Sukuk

The misperceptions about the Nahkeel Sukuk were related to government guarantees for the originator. The investors wrongly perceived that the sukuk had a guarantee of the Dubai government (Warde 2011) as the deal was guaranteed by Dubai World, a state-owned company. 
This implied that sukuk investors expected that the government of Dubai would bail out the sukuk if the obligor, Nahkeel Holding 1, and then Dubai World, would default on their payment obligations. The perceptions about the Nahkeel sukuk was not justified according to the extensive 237- page OC of Nahkeel sukuk ${ }^{31}$. The document explicitly comments on these aspects. While disclosing the risk factors related to Dubai World (the guarantor) and co-obligors, the OC says 'that the Government of Dubai does not guarantee any indebtedness or any other liability of Dubai World'. Also, it mentions that Dubai world is a holding company and it is dependent on the performance of its subsidiaries and, therefore, claims of the Dubai World creditors are subordinate to direct creditors of its subsidiaries ( p. 36). However, the rating agency, Standard \& Poor's, gave an $\mathrm{A}+$ rating to sukuk with a view 'that the purchase undertaking provided to DP World Sukuk from its parent [Dubai World] also benefited from strong implicit government support'(S\&P 2007). Considering the clear disclaimer about the government guarantee and absence of any other indication that government of Dubai would pay to the investors in case of insolvency, 'A+' rating appears to be 'exaggerated' and 'unwise' to some Islamic Finance experts $^{32}$. This became evident when the government of Dubai requested the creditors of Dubai World for a 6-month standstill, on November 25, 2009.

\section{Reasons for Insolvency/default}

In the aftermath of the global financial crisis 2007-09, the macroeconomic situation led the Dubai government to seek a standstill for USD59 billion debt owed by one of the state-owned companies Dubai World, including Islamic sukuk of 3.5 billion (Smith and Kiwan (2009)). There were various factors which caused Dubai World to in effect default. Huge short term borrowings, falling oil prices, the bursting of the real estate price bubble due to excessive supply of residential and commercial properties, and a liquidity mismatch owing to short term liabilities and long term receivables from the property development, all contributed to the failure of Dubai World, the guarantor of the Nahkeel sukuk, and its daughter companies (IMF (2010)).

There were ambiguities about the actual worth of Nahkeel properties used for execution of the transaction. Dubai Waterfront was valued around USD4.2 billion in 2006, more than the sukuk

\footnotetext{
${ }^{31}$ The document is available at http://www.kantakji.com/figh/Files/Markets/m135.pdf

${ }^{32}$ For details see $\mathrm{http}: / / \mathrm{www}$.islamicfinance.de/?q=node/719.
} 
amount, based on proposed development on 2 idle strips of land as yet generating no income (Sukuk Focus 2010). Moreover, the guarantee of Dubai World became troublesome as the holding company itself was also negatively affected by the financial crisis. Also, being a holding company, Dubai World may have superior creditors than sukuk holders. Nahkeel holding 2 actually used liquidity from other resources to pay the return on sukuk instead of the return on the underlying assets of the sukuk which were negligible.

In the end the sukuk's default was triggered by the specific financial condition of the obligor. The financial account of the Nahkeel PJSC, show that for the first half of year 2009, the company had a net exposure of AED 12.8 billion to the parent company Dubai World. The amount is more or less equal to the payment due on 14 December 2009 for the sukuk final payment (AED 12.9) ${ }^{33}$. It is more than likely that, if the concentration of funds in related parties had been managed prudently, the standstill request for at least the Nahkeel sukuk, could have been prevented.

Bailout

Outright default was eventually prevented through the bailout by Abu Dhabi at the eleventh hour and all the sukuk holders were paid out accordingly (IMF (2010)).

\section{Discussion and overview}

In the previous section we sketched the details of the originator, underlying sukuk structure, reasons for sukuk failure and discussed the restructuring process, if any, of the four sukuk defaults. In this section we discuss the general issues that arise out of the analysis of these four default episodes, issues that are clearly related to the structure of the sukuk, the extent to which these structures deviated from shariah standards as provided by the AAOIFI and best market practices, and we ask the question whether imperfect compliance to shariah standards played a role in the way the restructuring process evolved and the eventual outcome.

\subsection{Governing Law and the enforceability of Foreign Courts' Ruling in cross-border contracts}

While sukuk were essentially designed to comply with shariah, they were in practice governed by the English law, because some concepts, like SPVs, commonly used in conventional

\footnotetext{
${ }^{33}$ For more information see http://suqalmal.blogspot.nl/2009/12/nakheel-intercompany-funding.html
} 
financing, do not give the same rights to investors in some GCC jurisdictions following civil law. This has created problems for sukuk issuance in jurisdictions like Bahrain and UAE (Nazar (2011 )). In some states non-recognition of a SPV may render various contracts void. ${ }^{34}$ Especially the investors' right of recourse to underlying sukuk assets in the event of default proposed in the offering circulars then becomes ambiguous. There may be conflicts in some clauses of contracts governed by the English law with Islamic law (shariah). Several recent rulings of English courts clarify that in case of any contradiction between Islamic law and English law, the latter would prevail $^{35}$.

The sukuk issued in GCC countries have some common characteristics and associated issues owing to the specific laws of jurisdictions and provisions made in the offering letters that exposed investors to legal and credit (sukuk) default risk. Moreover, sukuk issued from various countries may have similar underlying contracts, but the implications of the contracts regarding investors' rights may be different because of the differences among the legal systems of the concerned jurisdictions. For instance, though both Kuwait-based TID and US-based ECP sukuk follow musharakah structure, but only in the latter case the sukuk holders could have recourse to the underlying sukuk asset thanks to US court ruling under common law system. Also, these sukuk have peculiar features which differentiate them from each other due to distinctive business nature of originators and clauses embedded in the sukuk contracts. Both the common and individual issues in the sukuk structures need to be addressed to avoid the anomalies in the sukuk industry and to protect the rights of the sukuk investors. Table 2 summaries all the features and issues related to the four sukuk being studied.

The best business practices require the contracts to be transparent and enforceable in order to protect the interests of the parties involved. Similarly, shariah endorses only those contracts which are free from gharrar (excessive uncertainty and speculations in the contract or transaction). ${ }^{36}$ On the contrary, there were some gray areas in the sukuk OCs issued in GCC region, which are the cause of gharrar. These sukuk are governed by the English laws as the main

\footnotetext{
${ }^{34}$ In Saudi Arabia declaration of trust is not recognized and therefore the contract in which trust (SPV) is a party may not be considered valid in the relevant courts (source: Saad sukuk OC).

${ }^{35}$ For instance, in one such case, the two parties involved were Beximco Pharmaceuticals Ltd vs Shamil Bank of Bahrain. The client defaulted on repayments of Murabahah loan, but it took stance that the transaction was not shariah compliant and thus should be cancelled by the court. However, court ruling rejected the argument of the Beximco declaring that English law is the governing law of the contract (Yean (2009 ))

${ }^{36}$ The instruments which are rendered void because of Gharar are forwards, futures, insurance, options, and other derivative securities ((Mohieldin (2012 )))
} 
sukuk documents like lease contracts, transaction documents and trust agreements are prepared under that law. The concepts in the English law may not exist in the relevant jurisdiction due to different legal system, causing legal risks to the investors. Moreover, any judgment under English law by a foreign court may not be implemented fully in GCC countries. Courts of the relevant jurisdictions may review the judgments in accordance with public policies of the state. For instances, in case of TID sukuk governed by English law, the English courts have jurisdiction to resolve the conflicts arising from the sukuk but the their judgments may not be vetted by the Kuwaiti courts in the absence of any agreement between Kuwait and UK for enforcement of courts’ ruling reciprocally. (El-Gamal (2007))

Likewise, in Golden Belt I (Saad) sukuk, the OC points out that Saudi Arabian law does not recognize the concept of trust as common law jurisdictions do (p. 30). Therefore, any agreement made in the capacity of the trust may not be legally recognized in Saudi law. It means that in the case of default sukuk investors may not claim their rights ordained in sukuk documents. However, authenticity of the trust would eventually depend on the discretion of the Saudi courts as there are some related concepts which do exist in Saudi Arabian law like wakalah (Agency Agreement). However, under the wakalah all the assets are registered in the name of agent/attorney and there is no exclusive entity for the trust. Moreover, English law governs the documents of head lease, sub lease, sukuk purchase agreement and service agreement in which Saad needs to pay for maintenance of the sukuk properties. In Saudi Arabia, similar to Kuwait, enforcement of the English courts' judgments has its limitations as the Saudi courts applying Islamic law may not recognize these rulings, especially in the absence of any precedent as well as bilateral treaty between Saudi Arabia and United Kingdom about these matters. Consequently, in the event of default if for example Saad fails to fulfill its obligations, sukuk holders may have insufficient assets of the obligor on which they have legal claims, since most of the assets of Saad are located in Saudi Arabia.

Similarly, concerning Nahkeel sukuk, UAE law does not recognize the concept of trust or beneficial interests and, therefore, terms of the Declaration of Trust may not be enforced by the courts of Dubai, though the agency concept does exist in UAE law (OC p.137). Also, the official circular noticeably mentions the uncertainties related to the UAE bankruptcy law in the wake of sukuk default and states that "There is little precedent to predict how claims by or on behalf of the Certificateholders would be resolved, and therefore there can be no assurance that 
Certificateholders would receive repayment of their claims in full or at all." Moreover, although English law is considered as the governing law of the Nahkeel sukuk, yet its enforceability in Dubai faces the same challenges as in Saudi Arabia and Kuwait, especially if government properties are involved in the dispute: no debt or other obligations owed by the government or rulers may be recovered through confiscating the properties of the government regardless of any foreign judgments.

\subsection{Ownership of the Sukuk Trust Assets: are the contracts bankruptcy proof?}

For sukuk to be shariah compliant, sukuk holders must have the ownership of the underlying real assets implying "tangible, usufruct rights or services, capable of being owned and sold legally" (AAOIFI (2008)). However, the GCC origin sukuk do not fulfill this requirement as the ownership of the underlying assets was not transferred to the sukuk holders properly from a legal point of view.

In the TID sukuk, however, the originator did contribute to musharakah (joint venture) through transferring "all rights, benefits and entitlements to the TID vehicles and property". However, section 2.5 (c ) of musharakah agreement mentioned that "registered title to the TID vehicles and property [musharakah assets] is held in the name of 'Investment Dar Company"' (p. 4) and the registration of the vehicles and property would remain in the name of TID with 'Traffic Department' and with 'Registration of Property Department in the Ministry of Justice.' So in the event of sukuk default, the investors did not have any direct recourse to the underlying assets of musharakah. Furthermore, section 2.5 (d) explained the status of this title retention, stating that TID "shall hold and maintain such registered title as agent for the Musharaka." Similarly, OC states (p. 11) "The certificates represent entitlements solely to the trust assets [in musharakah proportionally]." These last two points go in favor of the property rights of the sukuk investors in the underlying trust assets, but the final position can be determined through Kuwaiti court's ruling.

Similarly, in the Saad sukuk, the sukuk documents stipulated that following a dissolution or default event the sukuk holders would have recourse to so called trust assets only. These assets were defined as issuer's rights, interest and benefits under the Head Lease Agreement, the Sub-

Lease Agreement and the Promissory Notes. Thus Sukuk holders had a leasehold interest in the land parcels, but title of the land parcels remained in the name of chairman of Saad. Likewise, it 
was mentioned in the OC that being the head lessee the SPV has obtained only "limited representations”, i.e. leasehold interest, in land parcels ${ }^{37}$. Ownership of the assets was also clear under the head lease agreement as the chairman of Saad, being the owner, is responsible for all “all obligations, liabilities, rights and remedies, [...], including for loss of use, revenue or profit (as applicable) with respect to each of the Land Parcels,[...]. The Chairman of Saad will be responsible for the performance of all Major Maintenance.”

There was thus an incorrect perception that these sukuk were backed by real assets (Warde 2011). In practice, sukuk holders had rights only to the cash flows generated by the underlying assets and not to the assets itself as the title of the assets was not transferred to the buyer in the registers of the concerned departments of the government (e.g. Land Department). Further, leasehold rights were not considered as property right under Dubai law which restricts investors' claims and prosecution of law (Hassan and Kholid (2010)). Therefore, in case of default there was no recourse for the creditors to the original assets, the transfer of rights turned out not to be bankruptcy proof. So these sukuk essentially had the status of uncollateralized debt. Furthermore, though the prospectus declared a purchase agreement between originator and the SPV about sukuk assets (i.e. leasehold interest) against the price equivalent to the total amount of the sukuk, there are no regulations in UAE regarding the registration of these rights with Dubai Lands Department (OC-p 130). Thus the original contract was a lease and lease back contract instead of a sale and lease back contract. Logically therefore, the sukuk were considered as assetbased by the Moody’s (Howladar (2009)), not as asset backed.

The only instance in which the ownership of the sukuk was in fact transferred to the sukuk investors in a bankruptcy proof manner, was in the case of the US based ECP sukuk. In that case too, while applying for the chapter 11 bankruptcy protection, the originator asked the court to consider the primary transaction of ORRI in the contract as a secured loans and not as true sale, but the court did not accept the stance of the originator and considered the transaction as 'true sale'. Eventually, sukuk investors were considered the owner of ORRI.

\footnotetext{
${ }^{37}$ On the other hand, it is also mentioned (p. 26) that "The Issuer will have no material assets other than the Land Parcels which will be sub-let to the Sub-Lessee pursuant to the Sub-Lease Agreement."
} 


\subsection{Residual risk and Repurchase Undertakings as part of Sukuk}

Shariah principles do not allow an agreement to repurchase the sukuk at face value (repo) upon maturity as this arrangement renders sukuk identical to conventional bonds which are not permissible under Islamic law (AAOIFI (2008)). Because of this, credit risk became an issue for all of the sukuk amount plus outstanding rentals in case of an ijarah sukuk while it would otherwise have been limited to outstanding rentals and a risk of capital losses once the underlying assets are repurchased by the originator at the market price. Similarly, in musharakah sukuk equity of sukuk is transformed into debt but residual risk remains for the full amounts issued because of this stricture against repurchase agreements at fixed prices.

The three GCC based sukuk cases violated the abovementioned AAOIFI criterion. In the case of the TID musharkah sukuk, the originator company TID provides an undertaking in preliminary OC of to purchase the musharakah share of the issuer pursuant to:

(a) An 'Exercise Notice' by the issuer to purchase the issuer's units at 'Dissolution Distribution Amount' which was equivalent to the face value of sukuk plus any unpaid periodic distribution amount.

(b) Redemption notice to purchase the issuer's units at 'Early Redemption Amount' that was also equivalent to the face value of sukuk plus any unpaid periodic distribution amount.

(c) Occurrence of Dissolution Event, to purchase the issuer's units at 'Dissolution Distribution Amount'.

The purchase undertaking thus provided a put option to sukuk holders at the face value plus any unpaid periodic payment on sukuk. In practice, the credibility of this undertaking in Kuwait depends on the recognition of the 'trust agreement' by Kuwaiti courts and whether these courts consider a repurchase agreement as a guarantee. If so, the value of the implicit put depended on the financial position of TID. If the TID would be unable to meet the obligations under the repo, then sukuk would be ranked pari passu with other unsecured debts of the obligor since no ownership rights existed on the underlying assets.

Likewise, in the Saad sukuk, there was a repurchase undertaking by the Saad according to Sub Lease Agreement maturity date of the sukuk. There was also an early redemption option pursuant to which sukuk holders could ask the issuer to terminate the sublease contract if they 
would hold more than 25 percent of sukuk amount. Accordingly, the sukuk holders can ask Saad to pay the sukuk amount plus accrued rental payment using its rights under various promissory notes by Saad. The sukuk would be redeemed at face value plus any unpaid Periodic Distribution Amounts on the maturity of the sukuk. For further security Saad also issued a promissory note of USD650 million to support this repo.

\subsection{Credit Enhancement}

Credit enhancement is a technique through which the borrower increases its credit worthiness or at least the credit standing of the debt issued, in order to achieve better subscription, credit rating and pricing of the loan. Credit enhancment usually takes place through external guarantees, insurance and/or provision of collateral. In musharakah sukuk, it is not permissible for the manager of Sukuk acting as partner in musharakah to undertake to offer loan contracts with guaranteed returns when actual earnings fall short of expected earnings (AAOIFI (2008)), as the investors are obliged to share in profit and loss with the originator. However, a reserve account can be established to cover any shortfall in expected earnings.

Though in the TID musharakah sukuk, there is no explicit statement in OC stating that if the return on the sukuk are less than the offered rate 'LIBOR plus margin', the short fall would be covered by TID or any third party. However, it is mentioned generally in OC ( p. 11) that "The Issuer [...] would have direct recourse against TID to recover payments due to the Issuer from TID pursuant to the Transaction Documents to which it is a party.' This indicates that if the actual return of the sukuk holders is short of the LIBOR plus margin, issuer would have direct recourse to the TID. However, since the return of on the sukuk is ambiguous (see TID, $\underline{\text { Profit }}$ Distribution), sukuk may not have credit enhancements other than preferred access to a reserve account.

The US based ECP sukuk did establish a reserve account to cover any shortfall in the expected earnings in accordance with (AAOIFI (2008)) instructions.

Also, in the Saad ijarah sukuk, there was an explicit credit enhancement through payable rental promissory notes and promissory notes against (re)purchase undertakings. ${ }^{38}$ A promissory note about rental payments ensures the payment of promised sukuk returns if the sub-lessee fails

\footnotetext{
${ }^{38}$ Payable rental promissory notes are permissible under Islamic law but promissory notes against purchase undertaking to by the sukuk at face value are not.
} 
to pay the rental payment. These promissory notes make sukuk holders' claim pari passu to general creditors as these are governed by the Saudi laws. Similarly, Nahkeel sukuk had credit enhancement as the co-obligor guarantees the obligations of each co-obligor under the transaction documents (which also include lease documents) in which one of the obligation of co-obligors was to pay rental amount equal to payments to 6.345 percent per annum of the sukuk amount. ${ }^{39}$ Moreover, the Dubai World, the parent company, also guaranteed all of the co-obligors' payment obligations under the Transaction Documents.

\subsection{Limited Recourse}

There is thus only limited recourse to the sukuk's underlying assets in all GCC region sukuk. This means that sukuk represent beneficial ownership rights only in the trust assets and the sukuk investors have no recourse to the originator's assets nor the creditors of the originators have rights on the sukuk assets. However, as mentioned before, to have a recourse to the trust assets the ownership of the assets needs to be transferred to the SPV, acting as trustee of the sukuk holders. This was not done in the sukuk issued in GCC region.

TID musharakah sukuk mentions that proceeds of the trust are the only source of payments to the investors (p.7) in case of sukuk default. Thus, sukuk investors would not be treated pari passu with general creditors if the originator does not fulfill its obligations and thus defaults. In principle, a musharakah sukuk cannot default as the sukuk holder shares profit and loss with the originator. However as the originator promised a fixed return in TID sukuk contrary to musharakah principles, it can default on its obligations. In Saad's case, the only remedy was that sukuk holders can invoke their rights under sub-lease agreement and ask Saad (the sublessee) to pay the sukuk amount USD650 million plus accrued payable rental amounts. On the other hand, pursuant to transaction documents to which Saad was a party directly to the issuer, the issuer had a direct recourse against Saad to recover the accrued payments from Saad. However, getting an order for enforcement of Saad's obligations depended upon theb courts' discretion. Also, because of the Promissory notes, recourse of the sukuk holders would not be confined to the SPV assets only abut would include the obligor's assets as well.

\footnotetext{
${ }^{39}$ It is mentioned in the OC that 50percent of the six-month rental payment would be at the end of sukuk period. So the amount to be paid to the sukuk holders at the end of every six periods is equal to USD55,836,000 ( i.e. $3,520,000,000 * 0.5 * 0.06345 / 2$ )
} 
Similarly in Nahkeel sukuk it is disclosed in the OC that rights of the sukuk holders are limited to the trust /SPV assets, however due to the presence of various guarantees the investors hdid get claims on the assets of the obligors. But in case of an actual default, sukuk holders could not have recourse to the underlying assets.

\subsection{Role of the Shariah Boards}

Apparently, while deciding about the Shariah compliance of underlying sukuk structures, the administrative and procedural issues were generally overlooked by the shariah boards, especially in GCC originated sukuk. For instance, lawful transfer of the ownership of sukuk assets to sukuk holders, the status of the trust entity in concerned jurisdiction and earning capacity of the underlying sukuk assets to generate returns offered in sukuk documents was apparently ignored by the shariah board, with adverse implications when the sukuk issuers defaulted. In practice, the transfer of the ownership of the underlying sukuk assets was not accomplished legally in any of the three GCC based cases. In Nahkeel sukuk the property was overvalued and did not generate the proceeds in accordance with the returned offered on sukuk (Sukuk Focus 2010). Clearly, the potential capacity of the assets to generate the offered sukuk return was not checked adequately ex-ante. Also, in the TID musharakah sukuk, the transaction was backed by a credit enhancement mechanism in which the originator/manager of musharakah sukuk ensured the return by providing guarantees, against shariah strictures. Shariah compliance of the sukuk is the responsibility of the Shariah board, as is rightly emphasized by the AAOIFI ((2008)), but the board's performance seems to have been deficient in many cases. Hayat, Butter and Koch (2012), show that around twenty shariah scholars hold more than half of the market, and the top 3 receive about USD4.5 million as fees annually; it is clear that this market is beset by the same sort of incentive conflicts that we have seen in the case of regular rating agencies in Western finance: a strong incentive to be excessively lenient in certification i.e. a conflict of interest problem, sub-standard governance practices, lack of consensus regarding certification standards, and added to that in the case of the Sharia boards, limited knowledge of finance. 


\section{Conctusions}

Islamic finance instruments occupy a rapidly growing niche in world capital markets. Sukuk in particular have been presented as an alternative to interest based conventional bonds. They are often seen as asset backed securities free of interest and meeting the criteria of Islamic finance. Issued by Islamic and non-Islamic entities alike, sukuk promised access to a large pool of capital in the Islamic world while eliminating some of the high risk taking incentives characteristic of more conventional financial instruments.

Islamic strictures require investors to share risks with the entrepreneurs they finance. Thus, Islamic debt instruments are more equity-like than traditional debt instruments: Islamic debt instruments have loss absorption capacity and are thus more like hybrids, debt with equity characteristics. In the end Sukuk investors are supposed to share profit and loss in the underlying venture to a considerable extent. Sukuk come mostly in two varieties, musharakah (basically a joint venture agreement) and Ijarah (more like an operational lease agreement). In particular for musharakah (joint venture) sukuk, there should not have been any defaults, since all payments are contingent on profits and none are due if there are no profits. In the case of ijarah sukuk, the risks of sukuk investors are limited to default on periodic rental payments by the lessee and residual risk. These risks can be potentially mitigated through creating a reserve account and managing it prudently. Yet defaults did happen, even in the case of musharakah (joint venture) sukuk like the TID and ECP sukuk discussed in this study. So is Islamic finance failing to deliver on its promises?

To answer that question, we analyse four major defaults on Sukuk that have happened recently in the aftermath of the worldwide credit crisis that has engulfed the world since 2007. These case studies make clear that most of the problems that triggered defaults or blocked smooth resolution of distress afterwards, arose from ill-defined property rights and conceptual mismatches between relevant jurisdictions and the legal structures chosen. In most cases, the problems can be traced back to clauses and structures that made the Sukuk more like conventional bonds. For example, (i) in some cases, return on capital was ascertained with some promissory notes or guarantees by the originators or third parties (ii) repurchase undertaking by the originator/obligor to purchase the sukuk at face value on sukuk maturity date and (iii) credit enhancement. 
Such features rendered sukuk almost identical to conventional bonds which pay periodic interest and face value on redemption of the securities at the end. But introduction of conventional characteristics in sukuk created a situation in which there was a possibility for sukuk to default, like is the case with a conventional bond.

Furthermore, once default happened, most of the sukuk discussed did not transfer the underlying assets to the sukuk holders. So, in the event of default, due to limited recourse provisions, sukuk holders often had nothing to resort to, as effectively there were no underlying assets in their ownership. As a consequence, sukuk were treated as subordinated debt from the obligor/guarantor in distress situations. The case studies highlighted the importance of the legal institutions of the country where the collateral is likely to be contested. In the case of the US based ECP sukuk, underlying assets were in fact assigned to the Sukuk holders. This was a very important precedent about protection of sukuk holders' rights and would subsequently have a positive impact on sukuk growth in US since it set the precedent that asset backed sukuk are in fact bankruptcy proof: the transfer of assets to the Sukuk SPV was shown to be safe from bankruptcy of the originator company. Thus in the US, sukuk holders' rights are protected due to a well-developed legal system of collateral and recognition of all the contracts by the courts of law. But the situation was very different for the Sukuk issued under the jurisdiction of the Gulf countries. In the GCC countries, there is no historical precedent regarding sukuk holders claims which might protect the interest of the investors (Ryan and Elmalki (2010)).

Interestingly enough, strict adherence to shariah principles would have considerably simplified restructuring because shariah compliance implies a clear allocation of property rights: in shariah compliant instruments, investors will receive full title to the collateral in distress situations.

So the answer to the question we asked, is Islamic Finance failing to deliver on its promises, is a qualified no. Mishaps have happened and resolutions have been more mired in controversy than expected. But strict compliance to shariah principles of ownership and risk sharing would have reduced incidence of defaults and facilitated restructuring, as in particular the history of the ECP Sukuk demonstrates. The asset-backed structure of sukuk accompanied with a ban on derivatives and sale of debt, can thus potentially make the world a less risky place. However, the experience of the four default episodes shows clearly that benefits from the sukuk in accessing a wider investor base can only be achieved if the sukuk strictly follow the rules prescribed by the 
Islamic jurisprudence called shariah. These principles need sukuk to be asset-backed and free of interest, gharrar (excessive uncertainty/ambiguities) and gambling (Jobst (2007)). Also sukuk and all the legal constructs that form part of the arrangement should be recognized in the law of the jurisdiction concerned. Eligibility of Sukuk for secondary market trading would make then more liquid and so increase their attractiveness. ${ }^{40}$ An additional point that emerges from the case studies is the damaging impact of ambiguity concerning the shariah compliance status. In that respect, both the transparency of Sukuk and the resolution of distress situations would doubtlessly profit from further standardization. Increased codification of the requirements shariah compliance implies, and a further professionalisation of the Boards that decide on compliance are thus developments that would most likely increase acceptance of Islamic Finance in global capital markets and unlock the growing pool of capital in Islamic countries.

\section{References:}

AAOIFI, 2008, Accounting and auditing organization for islamic financial institutions.

Anwar, Haris, and Michael Patterson, 2009, Aston martin owner is first to default on gulf sukuk (Bloomberg).

Boustany, Iad G., Sleiman Roula, and Elias Sayegh, eds., 2005. Securitization in mena/gcc: Activity overview by asset class (Globe White Page Ltd, London).

Boustany, Iad Georges, 2006, New sukuk technology, (International Financing Review, Middle East).

El-Gamal , Mahmoud A., 2007, Mutuality as an antidote to rent-seeking shari‘a arbitrage in islamic finance, Thunderbird International Business Review.

El-Hawary, Dahlia, Wafik Grais, and Zamir Iqbal, 2004, Regulating islamic financial institutions: The nature of the regulated, Working Paper No. 3227 (World Bank Policy Research ).

Fidler, Stephen, 2009, Defaults pose latest snag in islamic-bond market, Wall Street Journal Halawi, Adnan, and Abir Atamech, 2012, Sukuk quarterly bulletin, (Zawya).

Hasan, Zulkifli, and Mehmet Asutay, 2011, An analysis of the courts' decisions on islamic finance disputes, ISRA International Journal of Islamic Finance 3.

Hassan , Kamal Abdelkarim , and Muhamad Kholid, 2010, Bankruptcy resolution and investor protection in sukuk markets, (QFINANCE).

Howladar, Khalid 2009, The future of sukuk: Substance over form? Understanding islamic securitization, asset-backed and aaoifi principles, (Moody's Investors Service).

IMF, 2010, United arab emirates: 2009 article iv consultation, IMF Country Report (International Monetary Fund).

\footnotetext{
${ }^{40}$ Debt based sukuk, like murabahah, are not eligible for secondary market trading according to most of the Islamic scholars except in East Asian countries as Malaysia and Indonesia.
} 
International Islamic Financial Market, 2009, 2009, A comprehensive study of the international sukuk market, Sukuk Report (International Islamic Financial Market, Manama).

Jobst, Andreas A., 2007, The economics of islamic finance and securitization, (International Monetary Fund, Washington DC).

Jobst, Andreas A., Peter Kunzel, Paul S. Mills, and Amadou N. R. Sy, 2008, Islamic bond issuance - what sovereign debt managers need to know, International Journal of Islamic and Middle Eastern Finance and Management 1, 330-344.

Khnifer, Mohammed 2010, When sukuk default - asset priority of certificate-holders vis a vis creditors, Opalesque Islamic Finance Intelligence

Latham, and Watkins, 2011, Case study-east cameron partners sukuk, in Latham and Watkins, ed.: Policy Brief on Corporate Governance for Islamic Banks and Financial Institutions in the Middle East and North Africa Region (Hawkamah, The Institute for Corporate Governance 2011).

McMillen, Michael J.T., 2011, An introduction to shari'ah considerations in bankruptcy and insolvency contexts and islamic finance's first bankruptcy (east cameron).

Mohieldin, Mahmoud 2012, Realizing the potential of islamic finance, (World Bank).

Nazar, Jhordy Kashoogie 2011, Regulatory and financial implications of sukuk's legal challenges for sustainable sukuk development in islamic capital market, 8th International Conference on Islamic Economics and Finance (Doha).

Ryan, Dennis , and Fawaz Elmalki, 2010, The untested waters of default in islamic finance., The Cayman Island Journal.

S\&P, 2009, General criteria: Standard \& poor's approach to rating sukuk, (Standard \& Poor's).

Salah, Omar, 2010, Dubai debt crisis: A legal analysis of the nakheel sukuk, Berkeley Journal International Publicist 4, 19-32.

Smith, Matt, and Enjy Kiwan, 2009, Dubai seeks debt delay, some units cut to junk, Reuters.

Stimpfle, Alexander 2011, Islamic finance made in germany: The 2004 sukuk issue by the state of saxony-anhalt, (GRIN Publishing GmbH., Munich).

Warde, Ibrahim, 2011, Islamic finance -bankruptcy, financial distress and debt restructuring: A short report, (Harvard Law School, Cambridge).

Yean, Wan Tan, 2009, Sukuk: Issues and the way forward, International Legal News. 


\section{Annex I: Tables}

Table 1: Key Terms of Various Sukuk

Table 2: Claims of Sukuk holders and Risks in Various Sukuk Issues 


\begin{tabular}{|c|c|c|c|c|c|}
\hline Sukuk Name & East Cameron & \multicolumn{2}{|c|}{ The Investment Dar Company Sukuk } & \multirow{2}{*}{$\begin{array}{l}\text { Golden Belt } 1 \text { Sukuk } \\
2007\end{array}$} & \multirow{2}{*}{$\begin{array}{c}\text { Nahkeel Sukuk } \\
2006\end{array}$} \\
\hline Year & 2006 & 2006 & 2005 & & \\
\hline Amount & USD165.67 million & USD150 million & USD100 million & USD650 million & $\begin{array}{l}\text { USD3,520 } \\
\text { million }\end{array}$ \\
\hline $\begin{array}{l}\text { Certificates } \\
\text { Structure: }\end{array}$ & Sukuk al-Musharakah & $\begin{array}{l}\text { Sukuk-al-Musharakah } \\
\text { (co-ownership/joint } \\
\text { venture) }\end{array}$ & $\begin{array}{l}\text { Sukuk-al-Musharaka } \\
\text { (co-ownership/joint } \\
\text { venture) }\end{array}$ & Sukuk Al-Ijarah (leasing) & $\begin{array}{l}\text { Sukuk Al-Ijarah } \\
\text { (leasing) }\end{array}$ \\
\hline Security & $\begin{array}{l}\text { Right on oil and gas } \\
\text { over-riding royalty } \\
\text { interests (“ORRI”) }\end{array}$ & $\begin{array}{l}\text { Unsecured, } \\
\text { unsubordinated }\end{array}$ & $\begin{array}{l}\text { Unsecured, } \\
\text { unsubordinated }\end{array}$ & $\begin{array}{l}\text { Promissory Note for the benefit of the } \\
\text { SPV by the Sub-Lessee equal to the } \\
\text { sukuk amount of USD } 650 \text { million and for } \\
\text { the periodic payable rental amount. }\end{array}$ & $\begin{array}{l}\text { Mortgage on } \\
\text { Trust Assets, } \\
\text { Guarantees }\end{array}$ \\
\hline Closing Date & July 2006 & $20-9-2006$ & $27-10-2005$ & $15-5-2007$ & \\
\hline Tenor & 13 years & 5 years & 5 years & 5 years & 3 years \\
\hline Listing & & $\begin{array}{l}\text { Dubai International } \\
\text { Financial Exchanges }\end{array}$ & $\begin{array}{l}\text { Bahrain Stock } \\
\text { Exchange. }\end{array}$ & Bahrain Stock Exchange & $\begin{array}{l}\text { Dubai } \\
\text { International } \\
\text { Financial } \\
\text { Exchange }\end{array}$ \\
\hline Final Maturity & 2019 & $\begin{array}{l}5 \text { Years from closing } \\
\text { date }\end{array}$ & $\begin{array}{l}5 \text { years from closing } \\
\text { date }\end{array}$ & $15-5-2012$ & $12-14-2009$ \\
\hline Rating & $\begin{array}{l}\text { CCC+ (Standard \& } \\
\text { Poor's) }\end{array}$ & A- by Moody’s & Unrated & BBB+ by S\&P and baa1by Moody’s & \\
\hline Return & 11.25percent & $\begin{array}{l}\text { Years 1-3: 6-month } \\
\text { LIBOR + } 125 \text { bps p.a. }\end{array}$ & $\begin{array}{l}6 \text { month LIBOR plus } \\
\text { 2percent p.a. on an }\end{array}$ & 6 month LIBOR+ 0.85 percent (Margin) & 6.345 percent p.a. \\
\hline
\end{tabular}




\begin{tabular}{|c|c|c|c|c|c|}
\hline & & $\begin{array}{l}\text { Years 4-5: 6-month } \\
\text { LIBOR + } 175 \text { bps p.a. }\end{array}$ & actual/360 day basis & & \\
\hline Governing law & USA & English law & $\begin{array}{l}\text { English law and } \\
\text { Bahrain law }\end{array}$ & $\begin{array}{l}\text { English law governs Trust, Agency and } \\
\text { Lease agreements. The Services } \\
\text { Agreement is governed by Bahrain law. } \\
\text { Saudi law governs promissory notes. }\end{array}$ & English law \\
\hline \multicolumn{6}{|l|}{ Key Parties } \\
\hline $\begin{array}{l}\text { Originator } \\
\text { /Obligor }\end{array}$ & $\begin{array}{l}\text { East Cameron Partners } \\
\text { (Texas, USA) }\end{array}$ & TID & TID & $\begin{array}{l}\text { Saad Trading, Contracting and Financial } \\
\text { Services Company }\end{array}$ & $\begin{array}{l}\text { Nahkeel Holding } \\
1\end{array}$ \\
\hline Issuer & $\begin{array}{l}\text { East Cameron Gas } \\
\text { Company (Cayman } \\
\text { Islands SPV) }\end{array}$ & $\begin{array}{l}\text { TID Global Sukuk I } \\
\text { Limited (SPV) } \\
\text { incorporated in Cayman } \\
\text { Island }\end{array}$ & $\begin{array}{l}\text { The Investment Dar } \\
\text { Sukuk Company } \\
\text { (SPC), incorporated in } \\
\text { Bahrain. }\end{array}$ & Golden Belt 1 Sukuk Company (SPV) & $\begin{array}{l}\text { Nahkeel } \\
\text { Development } \\
\text { Limited (SPV) }\end{array}$ \\
\hline $\begin{array}{l}\text { Arranger \& } \\
\text { Administrator } \\
\text { \& Bookrunner }\end{array}$ & $\begin{array}{l}\text { BSEC Bemo } \\
\text { Securitisation (Beirut, } \\
\text { Lebanon) }\end{array}$ & $\begin{array}{l}\text { Unicorn Investment } \\
\text { Bank B.S.C (c) and West } \\
\text { LB AG, London Branch }\end{array}$ & ABC Bank & BNP PARIBAS & $\begin{array}{l}\text { Dubai Islamic } \\
\text { Bank PJSC }\end{array}$ \\
\hline Trustee & The Issuer & The Issuer & The Issuer & $\begin{array}{l}\text { The Issuer, which then appointed Citicorp } \\
\text { Trustee Company Limited as trustee } \\
\text { delegate. }\end{array}$ & The Issuer \\
\hline
\end{tabular}




\begin{tabular}{|c|c|c|c|c|}
\hline $\begin{array}{l}\text { Sukuk } \\
\text { Features }\end{array}$ & Claims & Risks & Remedies & Comments \\
\hline \multirow{3}{*}{ 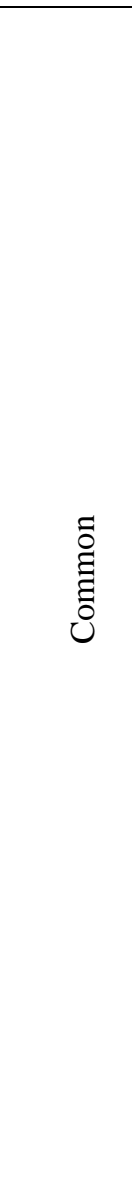 } & $\begin{array}{l}\text { All rights under } \\
\text { Declaration of Trust, the } \\
\text { Agency Agreements with } \\
\text { Issuer }\end{array}$ & $\begin{array}{l}\text { - Legal risk, as Declaration of Trust is not } \\
\text { recognized in the concerned Jurisdictions. } \\
\text { - Trust documents may be considered as } \\
\text { void then all rights of sukuk holders } \\
\text { become invalid. } \\
\text { - Investment loss risk. }\end{array}$ & $\begin{array}{l}\text { - Risks disclosed in OCs } \\
\text { - Promissory note issued to } \\
\text { pay the obligations (only } \\
\text { by Saad Sukuk) }\end{array}$ & $\begin{array}{l}\text { - Courts of the relevant jurisdictions } \\
\text { have discretionary powers regarding } \\
\text { validity of the trust documents. }\end{array}$ \\
\hline & $\begin{array}{l}\text { Claims under English } \\
\text { Governing Law }\end{array}$ & $\begin{array}{l}\text { - Only useful if concerned jurisdictions } \\
\text { have bilateral agreements. } \\
\text { • If the originator/obligor have enough } \\
\text { assets in jurisdictions functioning under } \\
\text { English law. } \\
\text { •There is no precedent of sukuk investors } \\
\text { claims resolution. } \\
\text { • Risk of loss of Investment }\end{array}$ & - Risks disclosed in OCs & $\begin{array}{l}\text { - Courts of the relevant jurisdictions } \\
\text { have discretion about applicability of } \\
\text { the foreign law. }\end{array}$ \\
\hline & $\begin{array}{l}\text { Judgments of the English } \\
\text { Courts }\end{array}$ & $\begin{array}{l}\text { - Limitations exist related to enforcement } \\
\text { of English court's ruling } \\
\text { - May be against the public policy of the } \\
\text { relevant jurisdictions. } \\
\text { - Risk of loss of Investment }\end{array}$ & - Risks disclosed in OCs & $\begin{array}{l}\text { - Courts of the relevant jurisdictions } \\
\text { have discretion about applicability } \\
\text { English courts' judgment. }\end{array}$ \\
\hline
\end{tabular}




\begin{tabular}{|c|c|c|c|}
\hline $\begin{array}{l}\text { Recourse to Underlying } \\
\text { Sukuk Assets in Case of } \\
\text { Default }\end{array}$ & $\begin{array}{l}\text { - Recourse is limited to the underlying } \\
\text { sukuk assets. } \\
\text { - Value of sukuk assets may depreciate } \\
\text { subject to market conditions. } \\
\text { - Title of sukuk assets not transferred to } \\
\text { sukuk investors. } \\
\text { - Possession of assets may not be acquired } \\
\text { in relevant jurisdictions in case of sukuk } \\
\text { default. } \\
\text { - Risk of loss of Investment } \\
\text { - No recourse to assets of } \\
\text { originators/obligors. }\end{array}$ & $\begin{array}{l}\text { • Risk of depreciation of } \\
\text { value of underlying sukuk } \\
\text { shifts to the obligor } \\
\text { pursuant to purchase } \\
\text { undertaking which ensures } \\
\text { repurchase of the sukuk at } \\
\text { face value. } \\
\text { • Promissory notes in Saad } \\
\text { sukuk and guarantees in } \\
\text { Nahkeel sukuk extends the } \\
\text { recourse to the obligors } \\
\text { assets. } \\
\text { - Risks disclosed in OCs }\end{array}$ & $\begin{array}{l}\text { - Titles of trust assets were not } \\
\text { transferred to sukuk holders in records } \\
\text { of the government departments. } \\
\text { Therefore, eventually sukuk holders did } \\
\text { not have any resource to underlying } \\
\text { assets. }\end{array}$ \\
\hline Underlying Sukuk Assets & $\begin{array}{l}\text { - Property valuation is inherently } \\
\text { subjective and uncertain. } \\
\text { Ownership/Title of the sukuk assets remain } \\
\text { in the name of the originator/ obligor. } \\
\text { • Effectively treated as debt Subordinated } \\
\text { to obligors assets (in case purchase } \\
\text { undertaking is recognized by the courts). } \\
\text { - Risk of loss of investment. }\end{array}$ & $\begin{array}{l}\text { - Disclosed formally in } \\
\text { OCs. }\end{array}$ & $\begin{array}{l}\text { - OCs show that issuer does have } \\
\text { underlying physical assets but } \\
\text { ironically the ownership of the assets } \\
\text { remain with the originator/obligor. } \\
\text { - That means in the case of default } \\
\text { sukuk holders own no assets legally. }\end{array}$ \\
\hline $\begin{array}{l}\text { Purchase Undertaking by } \\
\text { the originator to buy the } \\
\text { sukuk (sukuk redemption) } \\
\text { at face value. }\end{array}$ & $\begin{array}{l}\text { - Risk of obligors' default. } \\
\text { - Risk of non-recognition of repo as } \\
\text { guarantee. } \\
\text { - Risk attached to limited recourse to the } \\
\text { trust assets } \\
\text { - Risk of becoming subordinated debt. }\end{array}$ & $\begin{array}{l}\text { - Promissory note against } \\
\text { purchase undertaking of the } \\
\text { sukuk amount (only in case } \\
\text { of Saad's Golden Belt } 1 \\
\text { Sukuk). }\end{array}$ & $\begin{array}{l}\text { - Courts of the relevant jurisdictions } \\
\text { have discretionary powers to } \\
\text { (un)authenticate the contract. }\end{array}$ \\
\hline
\end{tabular}




\begin{tabular}{|c|c|c|c|c|}
\hline & Sukuk Returns & - Credit default risk & $\begin{array}{l}\text { - Guarantee/sureties are } \\
\text { provided in Nahkeel case. }\end{array}$ & $\begin{array}{l}\text { - OCs promise the payment of the } \\
\text { sukuk return without deducting any } \\
\text { taxes. } \\
\text { - In case of withholding taxes, the } \\
\text { same would be paid by the originator. }\end{array}$ \\
\hline & $\begin{array}{l}\text { Residual Risk of } \\
\text { Underlying Assets Borne } \\
\text { by the Obligor/Originator }\end{array}$ & - Credit default risk & $\begin{array}{l}\text { - Guarantee/sureties are } \\
\text { provided in Nahkeel case }\end{array}$ & $\begin{array}{l}\text { - The right is due to the purchase } \\
\text { undertaking to buy the sukuk at face } \\
\text { value at the end of sukuk period. }\end{array}$ \\
\hline $\begin{array}{l}\text { Investment } \\
\text { Dar Sukuk }\end{array}$ & $\begin{array}{l}\text { Credit Enhancement } \\
\text { through Direct Recourse } \\
\text { to the Investment Dar }\end{array}$ & $\begin{array}{l}\text { - Only implicitly mentioned. } \\
\text { • Direct recourse to the depends upon the } \\
\text { recognition of trust by Kuwaiti courts. } \\
\text { - No reserve account as the amount higher } \\
\text { than the periodic distribution profit amount } \\
\text { at aforesaid rate goes to manager TID as } \\
\text { an "incentive fees" }\end{array}$ & - No sureties are provided. & $\begin{array}{l}\text { - Kuwaiti courts have discretionary } \\
\text { powers regarding this matter. }\end{array}$ \\
\hline & $\begin{array}{l}\text { Ownership of } \\
\text { Musharakah Sukuk }\end{array}$ & $\begin{array}{l}\text { • Financial accounts of originator show } \\
\text { that sukuk are treated as liabilities in its } \\
\text { balance sheet. } \\
\text { - This show that underlying entire sukuk } \\
\text { assets of musharakah may be treated as the } \\
\text { TID assets, as musharakah assets are } \\
\text { registered in the name of 'Investment Dar } \\
\text { Company'. }\end{array}$ & $\begin{array}{l}\text { - Purchase undertaking of } \\
\text { musharakah assets from the } \\
\text { sukuk holders. }\end{array}$ & $\begin{array}{l}\text { - In default scenario, the courts needs } \\
\text { to decide the actual ownership of the } \\
\text { sukuk assets. }\end{array}$ \\
\hline
\end{tabular}




\begin{tabular}{|c|c|c|c|c|}
\hline $\begin{array}{l}\text { Saad's } \\
\text { Golden Belt } \\
1 \text { Sukuk }\end{array}$ & $\begin{array}{l}\text { Credit Enhancement } \\
\text { through Payable Rental } \\
\text { Promissory Note and } \\
\text { Promissory Note against } \\
\text { Purchase Undertaking }\end{array}$ & $\begin{array}{l}\text { - Credit default risk } \\
\text { - There is also shariah compliance risk as } \\
\text { the courts may consider the rent relatively } \\
\text { higher than the underlying assets' value } \\
\text { and thus against the principle of equity. }\end{array}$ & $\begin{array}{l}\text { - OC clearly discloses these } \\
\text { risks. }\end{array}$ & $\begin{array}{l}\text { - Promissory note make sukuk holders' } \\
\text { claim equal to general creditors as it is } \\
\text { governed by the Saudi laws. }\end{array}$ \\
\hline \multirow[t]{4}{*}{$\begin{array}{l}\text { Nahkeel } \\
\text { Sukuk }\end{array}$} & $\begin{array}{l}\text { Mortgages of the Nahkeel } \\
\text { Holding } 1 \text { properties. }\end{array}$ & $\begin{array}{l}\text { - Only recognized banks as lenders can } \\
\text { become a registered mortgagee in } \\
\text { government registers. Enforcement of } \\
\text { security by the Dubai Islamic Bank } \\
\text { (security agent) is untested in UAE courts } \\
\text { (OC pp-132). } \\
\text { - Court's order required to sell the } \\
\text { mortgaged property. }\end{array}$ & $\begin{array}{l}\text { - OC explicitly discloses } \\
\text { the risks. }\end{array}$ & $\begin{array}{l}\text { - The relevant courts have discretion } \\
\text { on the issue. }\end{array}$ \\
\hline & $\begin{array}{l}\text { Credit Enhancement via } \\
\text { Co-Obligor Guarantee } \\
\text { and Parent Company } \\
\text { Guarantee }\end{array}$ & $\begin{array}{l}\text { - These agreements are governed by } \\
\text { English law which may not be applied in } \\
\text { related jurisdiction. } \\
\text { - There are certain risks related to the co- } \\
\text { obligors and parent company. }\end{array}$ & $\begin{array}{l}\text { - The OC clearly mentions } \\
\text { all the risks related to the } \\
\text { counterparties and the } \\
\text { Dubai government does not } \\
\text { guarantee the deal. }\end{array}$ & $\begin{array}{l}\text { • Dubai courts have discretionary } \\
\text { powers regarding guarantees. } \\
\text { • In case guarantees are consider valid } \\
\text { sukuk would be subordinated to in the } \\
\text { indebtedness of the guarantors. }\end{array}$ \\
\hline & $\begin{array}{l}\text { Shares Pledge by co- } \\
\text { obligor Nahkeel Holding } \\
1 .\end{array}$ & $\begin{array}{l}\text { - Devaluation in share prices, especially } \\
\text { when the company becomes insolvent. }\end{array}$ & $\begin{array}{l}\text { - Risks about the co- } \\
\text { obligors are mentioned in } \\
\text { OC general. }\end{array}$ & \multirow{2}{*}{$\begin{array}{l}\text { - If the Nahkeel company is become } \\
\text { insolvent it share's value must decrease } \\
\text { as well. } \\
\text { - Also, Nahkeel company is the } \\
\text { developer of the land parcels } \\
\text { (underlying sukuk assets). }\end{array}$} \\
\hline & $\begin{array}{l}\text { Right to Subscribe Shares } \\
\text { of Nahkeel Company } \\
\text { (equity convertibility) }\end{array}$ & $\begin{array}{l}\text { - Of little worth if the originator is in } \\
\text { financial distress and markets already } \\
\text { perceived that. }\end{array}$ & $\begin{array}{l}\text { - Risks about the co- } \\
\text { obligors are mentioned in } \\
\text { general. }\end{array}$ & \\
\hline
\end{tabular}




\begin{tabular}{|c|c|c|c|}
\hline \multicolumn{4}{|l|}{ East Cameron Sukuk } \\
\hline $\begin{array}{l}\text { Underlying Asset, Oil and Gas } \\
\text { Hydrocarbons (Claim on } \\
\text { Reserves through Registered } \\
\text { Ownership of ORRI) }\end{array}$ & $\begin{array}{l}\text { • Legal risk. } \\
\text { • The underlying assets' value may } \\
\text { deplete. } \\
\text { • Bad event (e.g. Hurricane) risk. }\end{array}$ & $\begin{array}{l}\text { - Mortgage over licenses. } \\
\text { - ORRI can be sold in secondary } \\
\text { market. } \\
\text { - Insurance against physical } \\
\text { damage. }\end{array}$ & $\begin{array}{l}\text { - The originator asked the court to consider the } \\
\text { primary transaction contract as 'secured loans' } \\
\text { and not as 'true sale' of assets. } \\
\text { - The US courts recognized the ownership of } \\
\text { the sukuk holders in underlying assets. }\end{array}$ \\
\hline $\begin{array}{l}\text { Credit Enhancement through } \\
\text { USD9.5 million Reserve } \\
\text { Account }\end{array}$ & $\begin{array}{l}\text { - In case of continuous losses } \\
\text { reserves may not be sufficient }\end{array}$ & $\begin{array}{l}\text { - Reserve covers } 6 \text { months cash to } \\
\text { pay sukuk return. }\end{array}$ & $\begin{array}{l}\text { - Reserve account could not provide required } \\
\text { liquidity in the event of actual default. }\end{array}$ \\
\hline Periodical Redemption of Sukuk & - Counterparty risk & $\begin{array}{l}\text { - Reserve account is created for } \\
\text { this facility. }\end{array}$ & \\
\hline $\begin{array}{l}\text { Claim over Oil and Gas } \\
\text { Production and its Sale }\end{array}$ & $\begin{array}{l}\text { - Commodity Price Risk } \\
\text { - Offtake risk }\end{array}$ & $\begin{array}{l}\text { - Sukuk structure use conservative } \\
\text { commodity price projections. } \\
\text { - Commodity price hedges in } \\
\text { place to mitigate downside price } \\
\text { risk. } \\
\text { - Back up offtake agreement with } \\
\text { Merril Lynch to hedge the offtake } \\
\text { risk. }\end{array}$ & \\
\hline
\end{tabular}

